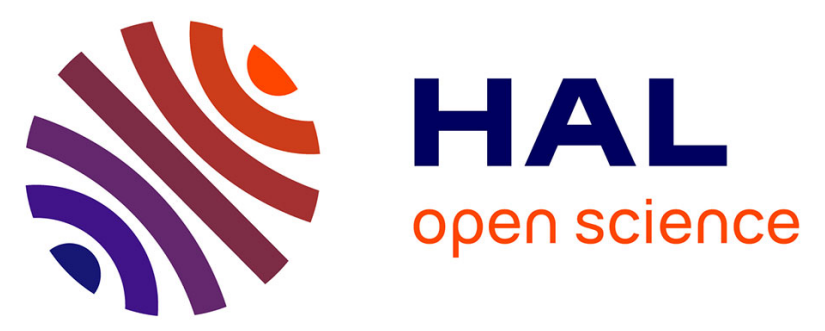

\title{
Changes in protein expression profiles in bovine endometrial epithelial cells exposed to E coli LPS challenge
}

Cristian Piras, Yongzhi Guo, Alessio Soggiu, Metasu Chanrot, Viviana Greco, Andrea Urbani, Gilles Charpigny, Luigi Bonizzi, Paola Roncada, Patrice Humblot

\section{To cite this version:}

Cristian Piras, Yongzhi Guo, Alessio Soggiu, Metasu Chanrot, Viviana Greco, et al.. Changes in protein expression profiles in bovine endometrial epithelial cells exposed to E coli LPS challenge. Molecular BioSystems, 2017, 13 (2), pp.392-405. 10.1039/c6mb00723f . hal-01604991

\section{HAL Id: hal-01604991 https://hal.science/hal-01604991}

Submitted on 25 May 2020

HAL is a multi-disciplinary open access archive for the deposit and dissemination of scientific research documents, whether they are published or not. The documents may come from teaching and research institutions in France or abroad, or from public or private research centers.
L'archive ouverte pluridisciplinaire HAL, est destinée au dépôt et à la diffusion de documents scientifiques de niveau recherche, publiés ou non, émanant des établissements d'enseignement et de recherche français ou étrangers, des laboratoires publics ou privés. 


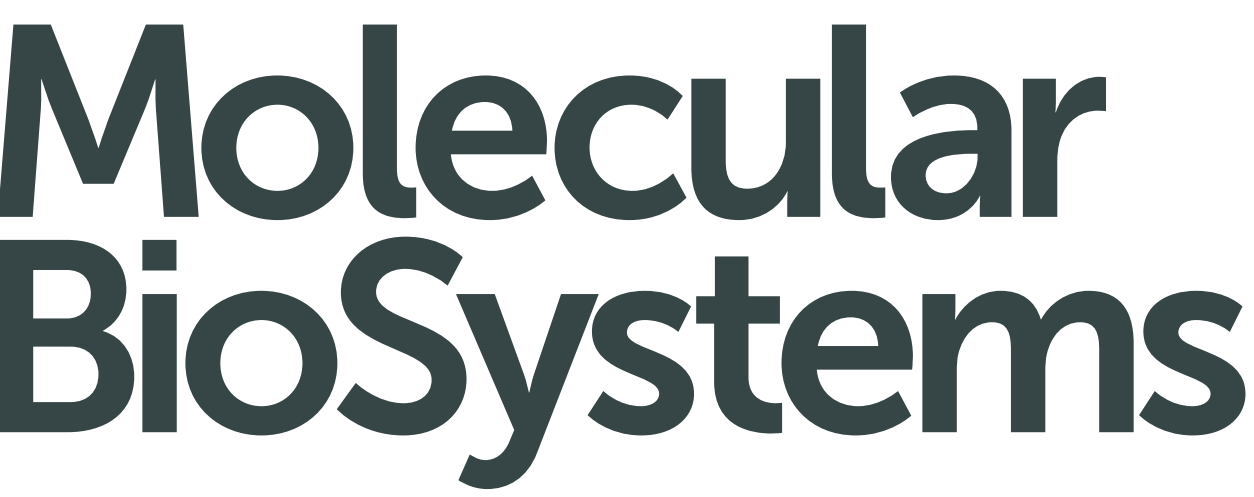

Accepted Manuscript

This article can be cited before page numbers have been issued, to do this please use: C. Piras, Y. Guo, A. Soggiu, M. Chanrot, V. Greco, A. Urbani, G. Charpigny, L. Bonizzi, P. Roncada and P. Humblot, Mol. BioSyst., 2016, DOI: 10.1039/C6MB00723F.

\section{Molecular BioSystems}

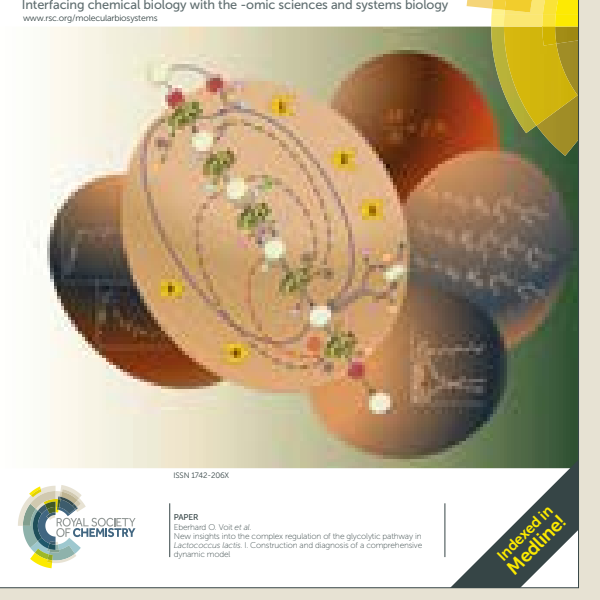

This is an Accepted Manuscript, which has been through the Royal Society of Chemistry peer review process and has been accepted for publication.

Accepted Manuscripts are published online shortly after acceptance, before technical editing, formatting and proof reading. Using this free service, authors can make their results available to the community, in citable form, before we publish the edited article. We will replace this Accepted Manuscript with the edited and formatted Advance Article as soon as it is available.

You can find more information about Accepted Manuscripts in the author guidelines.

Please note that technical editing may introduce minor changes to the text and/or graphics, which may alter content. The journal's standard Terms \& Conditions and the ethical guidelines, outlined in our author and reviewer resource centre, still apply. In no event shall the Royal Society of Chemistry be held responsible for any errors or omissions in this Accepted Manuscript or any consequences arising from the use of any information it contains. 


\title{
Changes in protein expression profiles in bovine Endometrial Epithelial Cells exposed to $E$ coli LPS challenge
}

\author{
Cristian Piras $^{a}$, Yongzhi Guo ${ }^{b}$, Alessio Soggiu ${ }^{a}$, Metasu Chanrot $^{b c}$, Viviana Greco ${ }^{d}$, Andrea Urbani ${ }^{e}$, \\ Gilles Charpigny, ${ }^{f}$ Luigi Bonizzi $^{a}$, Paola Roncada ${ }^{a g^{*}}$, Patrice Humblot ${ }^{b}$
}

a) Dipartimento di Medicina Veterinaria,, Università degli studi di Milano, Milano, Italy;

b) Division of Reproduction, Department of Clinical Sciences, Swedish University of Agricultural Sciences, SLU, Sweden

c) Rajamangala University of Srivijaya (RMUTSV), Thungyai, Thailand

d) Proteomics and Metabonomics Unit Fondazione Santa Lucia - IRCCS, Rome, Italy;

e) Istituto di Biochimica e Biochimica Clinica, Università Cattolica, Roma, Italy

f) INRA, Biologie du Développement et Reproduction, 78350, Jouy en Josas, France

g) Istituto Sperimentale Italiano L. Spallanzani, Milano and TechnologieS srl, Italy

* Corresponding author:

Correspondence: Dr. Paola Roncada, Istituto Sperimentale Italiano L. Spallanzani, via Celoria 10, 20133 Milano, Italy

E-mail: paola.roncada@istitutospallanzani.it or paola.roncada@gmail.com

\begin{abstract}
E coli is one of the most frequent bacteria involved in uterine diseases. Lipopolysaccharide (LPS) is a component of outer membrane of Gram-negative bacteria involved in the pathogenic processes leading to post-partum metritis and endometritis in cattle. It also causes inflammation of the endometrium. Increase of cell proliferation by LPS is part of the inflammatory process. The aim of this study was to investigate possible changes in protein expression in relation with the proliferative response of bEEC after challenge with $E$. coli-LPS. In vitro culture of $\mathrm{b} E E C$ was performed from cow genital tracts collected at slaughterhouse. On passage 5, bEEC from each of 9 cows ( 3 series of 3 cows) were exposed to 0,8 , and $16 \mu \mathrm{g} / \mathrm{ml}$ LPS for $72 \mathrm{hrs}$. At time 0 and $72 \mathrm{hrs}$ later, attached cells /living cells were counted and for each time and LPS dosage, cells were frozen for proteomic analyses. All samples from the 3 series were analyzed by 2-D gel electrophoresis coupled to MALDITOF/TOF mass spectrometry. The samples from the first series were submitted to shotgun nLCMS/MS analysis. From the whole differential proteomics analysis, 38 proteins were differentially expressed $(\mathrm{p}<0.05$ to $\mathrm{p}<0.001)$ following exposure to LPS. Among them, twenty-eight were found to be up-regulated in the LPS groups in comparison to control groups and ten were down-regulated. Differentially expressed proteins were associated to cell proliferation and apoptosis, transcription, destabilization of cell structure, oxidative stress, regulation of histones, allergy and general cell metabolism pathways. The de-regulations induced by LPS were consistent with the proliferative phenotype and indicated strong alterations of several cell functions. In addition, some of the differentially expressed proteins relates to pathways activated at time of implantation. The specific
\end{abstract}


changes induced through those signals may have negative consequences for the establishment of pregnancy. 


\section{Introduction}

Due to negative genetic correlations between milk production traits, and reproduction and health traits

${ }^{1}$ the genetic selection for high milk production potential has been associated in dairy cows with a reduction in fertility and an increased sensitivity to diseases ${ }^{2,3}$. Modern dairy cows are at high risk of suffering from uterine disease following calving and the number of exposed cows reached several millions per year in $\mathrm{EU}^{2-5}$. Exposed cows have low fertility, extended unproductive periods with high culling rates ${ }^{5,6}$ thus affecting herd economy since rearing replacement animals is one of the main source of economic losses and welfare due to short life. More costs result from treatment and associated milk withdrawal. The total costs of diagnosed uterine diseases, for farmers, dairy and breeding industries has been reported to reach 1.4 billion $€ /$ year in $\mathrm{EU}{ }^{6}$. This figure may be underestimated due to undiagnosed forms of uterine dysfunction leading to idiopathic infertility.

Dystocia and retained placenta predispose to uterine disease due to disruption of physical barriers to infection and perturbation of immune responses that should eliminate pathogens ${ }^{7}$. Metabolic imbalance is also influencing these processes as strong negative energy balance was reported to depress gene expression in relation to immunity in uterine tissue ${ }^{8-10}$.

In most epithelia, specific strains of Escherichia coli (E. coli) are major sources of infection. For the cow endometrium, E. coli is one of the most prevalent bacteria isolated in metritis ${ }^{6,11,12}$ and paves the way for infection by other bacteria or viruses ${ }^{13,14}$. A major component explaining the pathogenicity of $E$ coli is related to the interaction of LPS with the host tissue ${ }^{12,15}$. E coli LPS provokes the inflammation of the endometrium through a cascade of events well conserved in different tissues. The presence and the involvement of TLR4 in epithelial and stromal cells of the bovine endometrium has already been demonstrated by Cronin and colleagues ${ }^{16}$. LPS binding to Toll like 4 receptors triggers the production of pro-inflammatory cytokines, the attraction of immune cells in stromal tissue and a shift between PGF2 $\alpha$ and PGE2 production by the endometrium. The deregulation of cytokines, chemokines, growth factors and major histocompatibility complexes (MHC) is a part of the inflammatory processes affecting epithelial barriers. Diagnosed clinical symptoms are the basis for treatment. However, acute uterine infections are often followed by an asymptomatic persistent inflammation which remains untreated. For instance in the cow, it has been shown that the undiagnosed persistence of inflammation of the endometrium following infection contracted at parturition ${ }^{7,17}$ perturbs later the embryo-maternal interactions necessary to establish successful implantation thus impairing fertility ${ }^{5,6}$. However, the role of endometrial cells and more especially epithelial cells in the persistence of inflammation and mechanisms involved in infertility at this stage of pregnancy still have to be elucidated.

Successful implantation requires a balanced and accurate molecular communication between conceptus and maternal endometrium. Even a small imbalance due to former bacterial infection /LPS stimulation could affect negatively the dialogue between the mother and the embryo necessary for the establishment of pregnancy ${ }^{18}$. The increased activation of $\mathrm{NF \kappa B}$ and the secretion of proinflammatory and chemotactic cytokines that proved the activation of CD14 receptor was demonstrated bronchial epithelial cell lines ${ }^{19}$. The occurrence of endometritis linked to the production of cytokines has already been investigated through the analysis of mRNA expression ${ }^{20}$. The overexpression of IL-1alpha and IL-1-RN mRNA and the down-regulation of cPGES mRNA have been reported in cows with subclinical endometritis when compared to healthy cows. Authors found as well that the expression of CXCL5, IL1B, IL8 and TNF mRNA was significantly higher in cows with subclinical or clinical endometritis. This result came from analysis of mRNA expression of the transcripts involved in prostaglandin synthesis in the bovine endometrium ${ }^{20,21}$. The deregulation of these pathways induced by LPS in endometrial cells, was further illustrated by Oguejiofor et al., 2015, while using a wider transcriptomic approach. 
The differential protein expression in caruncular and intercaruncular areas during peri-implantation period has been described in ewes ${ }^{18}$. Authors used LC-MS/MS technique and highlighted the important role of structural proteins as actin in the implantation process.

A differential proteomics profiling of cows with endometritis has already been performed by using 2D electrophoresis on endometrial tissue ${ }^{22}$. Among differentially expressed proteins between healthy cows and endometritis cows, proteins such as peroxiredoxin and heat shock proteins were overexpressed ${ }^{22}$.

As described above, the response of endometrial tissue in terms of pro-inflammatory factors has already been documented from in vivo material generally combining different types of cells resulting in some heterogeneity of the analyzed tissue. Other limitations may have resulted from former proteomic approaches. Due to this, in the present study we investigated the changes induced by LPS at different concentration on a homogenous population of post-primary bovine endometrial epithelial cells (bEECs) and by using two complementary proteomics approaches (2D electrophoresis and shotgun MS analysis). By using this combination, it was expected to find proteins patterns that may reveal the consequences of previous infection in the endometrial epithelium.

The information brought here showing that a multiplicity of pathways are deregulated by LPS provides new insights on the mechanisms involved in persistent inflammation following bacterial infection and suggest new perspectives to limit the impact of inflammation on the endometrial epithelium.

\section{Material and methods}

\section{Sample selection and endometrial epithelial cell culture.}

Bovine uteri without any morphological signs of inflammation were collected from a slaughter house and brought back on ice to laboratory within 1 hour after collection. Stage of the estrus cycle was determined at first from ovarian morphology and presence or absence of mucus in the uterine body. Genital tracts from 9 cows, showing an orange $C L>15 \mathrm{~mm}$ diameter and without abundant mucus were estimated to be associated with luteal phase 23 and subsequently used for cell culture. Stage of the cycle was further confirmed by histology from measurement of number of cross sections of the glands in full sections of the endometrium taken $5 \mathrm{~cm}$ from the tip of the horn 24 . The left uterine horns were dissected and cut into 5-6 $\mathrm{cm}$ long and 4-5 $\mathrm{mm}$ deep pieces. Uterine tissue was digested with collagenase IV (C5138, Sigma) and hyaluronidase (250 U/mL; H3506, Sigma) diluted in PBS (phosphate-buffered saline) plus $2 \% \mathrm{BSA}$ while stirring for 2 hours at $39^{\circ} \mathrm{C}$. The suspension was then filtered through a $250 \mu \mathrm{m}$ gauze to remove residual mucus and undigested tissue. The filtrate was then passed through a $40 \mu \mathrm{m}$ nylon sieve, which allowed the fibroblast and blood cells to pass through while epithelial cells were retained. Epithelial cells were collected from the filter by backwashing with $30 \mathrm{~mL}$ PBS. Cells were centrifuged at $170 \mathrm{~g}$ for 6 minutes and the pellet was re-suspended in 3 $\mathrm{mL}$ of PBS. To disperse pellet into a single cell suspension, cells were disrupted by passing through a fine gauge needle. Then, cells were cultured in F-12 medium (Dulbecco's modified eagle's medium, Sigma D6434) contained 10\% Fetal Bovine Serum (FBS), $50 \mathrm{U} / \mathrm{mL}$ of Penicillin/streptomycin, $2 \mathrm{mM}$ L- glutamine, $0.5 \times$ Liquid Media Supplement (ITS, I3146, Sigma), $10 \mu \mathrm{g} / \mathrm{mL}$ gentamycin and 100 $\mathrm{U} / \mathrm{mL}$ nystatin. Cells were seeded into a $25 \mathrm{~cm} 2$ ventilation flask and cell cultures kept in a waterjacked incubator with $5 \% \mathrm{CO} 2$ at $39^{\circ} \mathrm{C}$. Medium was changed every 1-2 days. Sub-cultivations were 
performed at 5-6 days when epithelial cells attained 80 to $90 \%$ confluence. The process was renewed until passage 4 and cells exposed to LPS challenge. LPS powder was dissolved in water $5 \mathrm{mg} / \mathrm{ml}$ as a stock. Before challenge, the adjusted concentrations of LPS and media were completely mixed. At 72 hours following LPS challenge, the supernatant was removed and non-adherent (floating) cells in media were counted under microscope by using a burker neubauer chamber (hemocytometer, 40443001, Hecht Assistent ${ }^{\circledR}$, Rhon, Germany). The attached cells were then detached with trypsin (TrypleTMExpress, gibco ${ }^{\circ}$, Waltham, USA). Cells were exposed systematically two times to $4 \mathrm{~mL}$ trypsin at $39^{\circ} \mathrm{C}$ for 4 minutes. Flasks were then checked for remaining cells. This protocol was applied again when some cells remained attached. After trypsinization, all cells were pipetted from flasks and then transferred into $15 \mathrm{~mL}$ falcon tubes. The solution was gently mixed for 2-3 seconds and $70 \mu \mathrm{L}$ taken and mixed with the same volume of trypan blue solution (T8154 trypan blue solution $0.4 \%$, Sigma ${ }^{\circledR}$, St.Louis, MO, USA) in Eppendorf tubes. Then, $10 \mu \mathrm{L}$ of mixed solution was immediately transferred to the counting chamber (same as above) following manufacturer's instructions. The living cells were detached with trypsin and pellets of 2 to 3 million post-primary cells per group were collected and immediately deep frozen $\left(-80^{\circ} \mathrm{c}\right)$ until subsequent proteomic analyzes ${ }^{23}$.

\section{LPS Challenges}

In preliminary experiments, epithelial endometrial cells were exposed to a wide range of concentrations of LPS reflecting concentrations found in uterine fluid in case of clinical endometritis 24 and cell survival was estimated ${ }^{25}$. The dosages of LPS used in the present experiment (Sigma L2630 E.coli O111:B4, 0 as controls, 8 and $16 \mu \mathrm{g} / \mathrm{ml}$ ) were chosen according to epithelial cell survival at 72 hours which was shown to be maximal with $8 \mu \mathrm{g} / \mathrm{ml}$ LPS ( +30 to $+40 \%$ living cells when compared to controls). This increase in cell survival progressively vanished with increasing dosage, cell survival being not different from controls following addition of $16 \mu \mathrm{g} / \mathrm{ml}$ and being lower than controls at higher dosages.

LPS challenges $(0,8$ and $16 \mu \mathrm{g} / \mathrm{ml}$ LPS) were applied on cells issued from 9 different cows (in 3 series of 3 cows). Living cells were counted by trypan blue staining and cell survival profiles at 72 hours obtained from this precise subset of cows, measured as (number of cells "LPS treated" number of cells "controls" / number of cells "controls") were analyzed by ANOVA (SAS ver 9.2, proc GLM). Effects of cow, series of experiments and LPS dosage on cell survival were analyzed by ANOVA (SAS Ver 9.2, proc GLM). The cow ID (9 levels; 3 different cows in each of 3 series), the series No (3 levels) and LPS dosage (2 levels) were included in the model as well as LPS x cow and LPS $x$ series interactions. The tests were made while comparing the LSmean ratio, observed for a given factor (or second order interactions) to 0 , which should be the mean value observed if these ratios were distributed at random. LS means ratios (either negative or positive) corresponding to the effect of LPS differing from 0 at $\mathrm{p}<0.05$ were considered as significant.

\section{Proteomics analyses}

Proteomic analyses have been performed according to Figure 1. All 9 biological replicates have been analyzed in groups of three through 2D electrophoresis followed by MALDI TOF MS for protein identification. Moreover, the first three biological replicates have been analyzed through label-free nanoflow liquid chromatography mass spectrometry $\left(\mathrm{nLC}-\mathrm{MS}^{\mathrm{E}}\right)$ analysis and each run was performed in triplicate.

Extraction of cell samples

Cellular pellets (cell amounts per pellet varied from $1,6 \times 10^{6}$ to $3,3 \times 10^{6}$ ) have been solubilized in a buffer containing $7 \mathrm{M}$ urea, $2 \mathrm{M}$ thiourea and $2 \%$ chaps with protease inhibitors. Briefly, the frozen 
pellet has been defrosted in ice and centrifuged for 10 minutes at $14000 \mathrm{rpm}$ for 10 minutes. The supernatant was carefully discarded and remaining pellets then solubilized with $20 \mu \mathrm{l}$ of the above described buffer (7M urea, 2M thiourea and 2\% CHAPS). Samples were solubilized with 2 cycles of $1 \mathrm{~h}$ under magnetic gentle stirring interspersed by $1 \mathrm{~h}$ at room temperature. The sample have been subsequently sonicated for 20 minutes and then centrifuged for 10 minutes at $10000 \mathrm{rpm}$ at room temperature. The pellet has been discarded and the supernatant with the extracted proteins frozen at $20{ }^{\circ} \mathrm{C}$ until use. Protein quantification has been performed using BioRad Protein Assay quantification kit.

\section{D electrophoresis and image analysis}

From each sample, 100 micrograms protein have been loaded in a $7 \mathrm{~cm}$ strip through active rehydration performed over night at $50 \mathrm{~V}$ in a buffer containing (7M urea, $2 \mathrm{M}$ thiourea, $2 \%$ CHAPS, 0,5\% Ampholytes 3-10 Amersham, $26 \mathrm{mM}$ DTT). Isoelectric focusing (IEF) was performed on a protean IEF platform using the following protocol: $100 \mathrm{~V} / 1 \mathrm{~h}$ linear, $250 \mathrm{~V} / 2 \mathrm{~h}$ linear, $4000 \mathrm{~V} / 5 \mathrm{~h}$ linear, $4000 \mathrm{~V}$ step $/ 50000$ total volt- hours (VhT). When the final amount of VhT was reached, immobilized $\mathrm{pH}$ gradient (IPG) strips have been frozen up to the next step or directly equilibrated in two steps of 15 minutes under gentle stirring. The first one was performed in equilibration buffer (6 M UREA, 2\% SDS, $0.05 \mathrm{M}$ Tris-HCl pH8.8, 20\% glycerol) supplemented with 1\% DTT w/v and the second one with addition of $2,5 \% \mathrm{w} / \mathrm{v}$ iodoacetamide. After this equilibration step, the IPG strips were loaded in a $12 \%$ home made acrylamide gel and IEF run under constant amperage of $15 \mathrm{~mA}$ per gel up to the Bromophenol Blue (BFB) reached the front.

The gels have been then removed from the plates, washed three times with double-distilled water and stained over night $(\mathrm{ON})$ with Coomassie Brilliant Blue.

Gels have been digitized using an Imagescanner III (GE Healthcare) and image analysis was performed using SameSpots software (Version 4.5, Nonlinear Dynamics U.K.). Spots with a p value lower than 0.05 were manually excised and subjected to mass spectrometry (MS) analysis and protein identification. The protein identification was performed according to the methodological protocol previously described ${ }^{26-29}$. Briefly, after steps of dehydration, reduction and alkylation, single spots were digested with a solution of $0.01 \mu \mathrm{g} / \mu \mathrm{l}$ of porcine trypsin (Promega, Madison, WI) at $37^{\circ} \mathrm{C}$ for 16 h. Peptides were concentrated using C18 ZipTip (Millipore) and then were spotted on a Ground Steel plate (Bruker-Daltonics, Bremen, Germany).

\section{MALDI TOF TOF MS Analysis}

The Peptide Mass Fingerprinting Analysis was performed according to Piras et al ${ }^{30}$ Briefly, the MS analysis was performed on an Ultraflex III MALDI-TOF/TOF spectrometer (BrukerDaltonics) in positive reflectron mode and MS spectra were analyzed by FlexAnalysis 3.3 software (Bruker-Daltonics) to select monoisotopic peptide masses. The external calibration was done by the standard peptide mixture calibration (Bruker-Daltonics: m/z: 1046.5418, 1296.6848, 1347.7354, 1619.8223, 2093.0862, 2465.1983, 3147.4710).

After an internal calibration (known autolysis peaks of trypsin, m/z: 842.509 and 2211.104) and exclusion of contaminant ions (known matrix and human keratin peaks), the created peak lists were analyzed by MASCOT v.2.4.1 algorithm (www.matrixscience.com) against SwissProt database released 2013_12 (25 245 entries) restricted to Bos taurus taxonomy. Database search was performed according these parameters: carbamidomethylation of cysteines as fixed modification; oxidation on methionines as variable modification; one missed cleavage site set for trypsin; maximal tolerance was established at $70 \mathrm{ppm}$. For protein identification assignment, only Mascot scores higher than 56 were considered significant $(\mathrm{p}<0.05)$.

To confirm the PMF identifications, the instrument was switched in LIFT mode with $4-8 \times 10^{3}$ laser shots using the instrument calibration file. For the fragmentation, precursor ions were manually selected and the precursor mass window was automatically set. Each MS/MS spectra acquired were 
processed by spectra baseline subtraction, smoothing (Savitsky-Golay) and centroiding using FlexAnalysis 3.3 software. For searching analysis, these parameters were set: carbamidomethylation of cysteines and oxidation on methionine respectively among fixed and variable modifications; maximum of one missed cleavage; the mass tolerance to $50 \mathrm{ppm}$ for precursor ions and to a maximum of $0.5 \mathrm{Da}$ for fragments. The taxonomy was restricted to Bos taurus. The confidence interval for protein identification was set to $95 \%(\mathrm{p}<0.05)$ and only peptides with an individual ion score above the identity threshold were considered correctly identified.

\section{Statistical analysis for validation of 2-DE dataset}

For a subset of 5 proteins, the repeatability of the results over the 3 series of analyses has been studied. From mean MS results from the 3 technical replicates of each sample the ratio of expression when compared to control was calculated and results analyzed by ANOVA (SAS Ver 9.2, proc GLM). The cow ID (9 levels; 3 different cows in each of 3 series), the series No (3 levels) and LPS dosage ( 2 levels) were included in the model as well as LPS x cow and LPS $\mathrm{x}$ series interactions. The tests were made while comparing the LSmean ratio, observed for a given factor (or second order interactions) to 0 , which should be the mean value observed if these ratios were distributed at random. For a given protein, ratios of expression (either negative or positive) corresponding to the effect of LPS differing from 0 at $\mathrm{p}<0.05$ were considered as significant through the 3 series of experiments.

Expression Analysis by $n L C-M S^{E}$.

Label-free nanoflow liquid chromatography mass spectrometry $\left(\mathrm{nLC}-\mathrm{MS}^{\mathrm{E}}\right)$ was performed as previously described in ${ }^{30-32}$. Briefly, the protein extracts of nine biological samples ( 3 dosages LPS from cell culture from 3 cows) were precipitated with a cold mix of Ethanol, Methanol, and Acetone (ratio 2:1:1, v/v), then dissolved in $6 \mathrm{M}$ Urea, $100 \mathrm{mM}$ Tris $\mathrm{pH} 7.5$ and digested 50:1 (w/w) with sequence grade trypsin (Promega, Madison, WI, USA) at $37^{\circ} \mathrm{C}$ overnight after reduction with $10 \mathrm{mM}$ DTT and alkylation with $20 \mathrm{mM}$ IAA. The reaction was stopped by adding a final concentration of $0.1 \%$ TFA. Separation of tryptic peptides and subsequent qualitative and quantitative $\mathrm{nLC}-\mathrm{MS}^{\mathrm{E}}$ analysis were performed by nanoACQUITY UPLC System (Waters Corp., Milford, MA) coupled to a Q-Tof Premier mass spectrometer (Waters Corp., Manchester, U.K.). An amount of $200 \mathrm{fmol} / \mu \mathrm{l}$ of digestion of Enolase from Saccharomyces cerevisiae was added to each sample as internal standard, then a final concentration of $0.6 \mu \mathrm{g}$ of protein digestion was loaded on column for peptides separation. Peptides were loaded onto a Symmetry C18 $5 \mu \mathrm{m}, 180 \mu \mathrm{m}$ x $20 \mathrm{~mm}$ precolumn (Waters Corp.) and subsequently separated by a $170 \mathrm{~min}$ reversed phase gradient at $250 \mathrm{~nL} / \mathrm{min}(3-40 \%$ $\mathrm{CH}_{3} \mathrm{CN}$ over $145 \mathrm{~min}$ ) using a NanoEase BEH C18 $1.7 \mu \mathrm{m}, 75 \mu \mathrm{mX} 25 \mathrm{~cm}$ nanoscale LC column (Waters Corp.) maintained at $35{ }^{\circ} \mathrm{C}$. The Q-Tof Premier mass spectrometer directly coupled to the chromatographic system operated in "Expression Mode" switching between low (4 eV) and high $(15-40 \mathrm{eV})$ collision energies on the gas cell, using a scan time of $1.5 \mathrm{~s}$ per function over 50-1990 $\mathrm{m} / \mathrm{z}$. The processing of low and elevated energy, added to the data of the reference lock mass, provides a time-aligned inventory of accurate mass-retention time components for both the low and elevated-energy (EMRT, exact mass retention time).

Each sample was run in three technical replicates. For qualitative and quantitative analysis, LC-MS data from three replicates experiments for each nine samples were processed using ProteinLynx GlobalServer v.3.0.2 (PLGS, Waters Corporation). Protein identifications were obtained with the embedded ion accounting algorithm of the software searching into UniProtKB/Swiss-Prot Bos taurus database release 2013_12 (25 245 entries) to which the sequence of enolase (UniProtKB/Swiss-Prot AC: P00924) was appended. The search parameters were set at: automatic tolerance for precursor ions and for product ions, minimum 3 fragment ions matched per peptide, minimum 7 fragment ions matched per protein, minimum 2 peptide matched per protein, 1 missed cleavage, carbamydomethylation of cysteines and oxidation of methionines as fixed and variable modifications, 
false positive rate (FPR) of the identification algorithm under $1 \%$ and $200 \mathrm{fmol}$ of the enolase internal standard set as calibration protein concentration. The most reproducible proteotypic peptides for retention time and intensity of enolase digestion $(\mathrm{m} / \mathrm{z} 814.49 ; \mathrm{m} / \mathrm{z} 1159.59 ; \mathrm{m} / \mathrm{z} 1288.70 ; \mathrm{m} / \mathrm{z}$ $1755.95 ; \mathrm{m} / \mathrm{z} 1840.91, \mathrm{~m} / \mathrm{z} 2441.12$ ) were used to normalize the EMRTs table. The expression analysis was performed considering 3 technical replicates available for each experimental condition (i.e., one experimental condition, control, LPS 8 and LPS 16 groups, $\times$ three biological replicates $\times$ three technical replicates). The list of normalized proteins was screened according to the following criteria: protein identified in at least 2 out of 3 runs of the same sample with a fold change of regulation higher than $+/-20 \%$; We considered significant only differentially expressed proteins with a $\mathrm{p}$ value $<0.05$. Finally, the GO Molecular function classification from the Panther Classification System $^{33}$ was used to allocate the differentially expressed proteins into functional groups according to the best fitness in the biological system analyzed.

\section{Results}

\section{Cell survival profiles following LPS challenges}

The profile of cell survival following LPS challenges made in the subset of cows used in this study was very similar to those observed in former experiments. A strong increase in cell survival was observed with the $8 \mu \mathrm{g} / \mathrm{ml}$ LPS dosage $(+24 \%, \mathrm{p}<0.0001)$ whereas results were not different from controls for the $16 \mu \mathrm{g} / \mathrm{ml}$ LPS group $(0.4 \%$, NS).

\section{Proteomic profiling from $2 D$ electrophoresis coupled with MALDI TOF TOF}

From 2D electrophoresis and imaging analyses a total of 1096 different spots were visualized (Figure 2) from pellets of endometrial epithelial cells and proteins subsequently identified from MALDI TOF TOF MS analysis. From those, a total of 7 proteins were found to be differentially expressed between controls and LPS treated samples (Table 1).

The different types of responses obtained according to LPS dosage are presented in Figure 3.

Results obtained by 2D electrophoresis coupled with MALDI TOF identification revealed that response to LPS was similar over the 3 groups of experiments for 5 proteins especially for the $8 \mu \mathrm{g} / \mathrm{ml}$ dosage whereas response was more variable for the $16 \mu \mathrm{g} / \mathrm{ml}$ LPS dosage. For all these proteins no significant interaction between LPS dosage and series was found. Annexin 2 was significantly under expressed for the $8 \mu \mathrm{g} / \mathrm{ml}$ dosage $(\mathrm{p}<0.02)$ but only a similar trend was observed for the $16 \mu \mathrm{g} / \mathrm{ml} \mathrm{LPS}$ dosage (Figure 4). On the contrary, Eukaryotic Initiation Factor 4A1 (EIF 4A1), Protein Disulfide isomerase (PDIA3), Superoxide Dismutase and Transketolase were significantly overexpressed following the $8 \mu \mathrm{g} / \mathrm{ml}$ LPS challenge ( $\mathrm{p}<0.001$ to $\mathrm{p}<0.05$ ). Similar effects were seen with $16 \mu \mathrm{g} / \mathrm{ml}$ but only a trend was seen for EIF 4A1. For all proteins, differences between 8 and $16 \mu \mathrm{g} / \mathrm{ml}$ LPS are nonsignificant.

\section{Proteomic profiling from shotgun MS and analysis of differentially expressed pathways.}

Shotgun MS analysis qualitatively identified a total of 226145 EMRTs and 160 proteins across all conditions. Quantification was performed following analysis of EMRTs and protein normalization. ${ }^{34}$, ${ }^{35}$ The overall statistical analysis from shotgun MS highlighted 35 differentially expressed proteins between the three different experimental groups (Table 1, fig. 5). These divide into 25 up regulated and 10 down regulated for at least one of the LPS dosage when compared to controls $(\mathrm{p}<0.05)$.

From Panther Classification System and use of GO Molecular function classification the differentially expressed proteins clustered well in structural proteins, metabolism proteins (energy metabolism), transcription and protein synthesis, oxidative stress, cell growth/apoptosis, immune response, and chromatin DNA binding pathways. 
Structural/Cytoskeleton, calcium metabolism and membrane properties: Structural proteins such as actin, peripherin and related proteins that contribute to actin stabilization and anchorage on plasma membrane such as radixin and tropomyosin alpha 1 chain are strongly down-regulated in both LPS groups in comparison to control group. On the contrary, Tropomyosin alpha 3 chain is upregulated with both LPS dosages. Proteins involved in cell membrane function and calcium metabolism are either down (annexin A1 and annexin A2, both LPS dosages) or up regulated (calreticulin both LPS dosages).

Protein disulfide isomerase (P4HB) and protein disulfide isomerase A3 (PDIA3) are both upregulated. In addition, a strong down-regulation of a protein with proteolytic activity (Cathepsin) and an up-regulation of a strong inhibitor of endopeptidases (Cystatin-B) in LPS8 group versus control group were observed.

Energy Metabolism: All proteins clustering in this category are strongly upregulated for both LPS dosages. This includes phosphoglycerate mutase, glyceraldehyde-3-phosphate deshydrogenase, triosephosphate isomerase and $\beta$ enolase, all of them being part of the glycolytic process.

Oxidative stress: All proteins involved in oxidative stress response and protein folding and refolding have been found to be overexpressed following LPS treatment. Among them peroxiredoxin, protein disulfide-isomerase, protein disulfide-isomerase A3, endoplasmin, SH3 domain binding glutamic acid rich like protein 3 and heat shock related 70KDA protein -2 . For most of them overexpression is a little bit higher with the 16 than for the $8 \mu \mathrm{g} / \mathrm{ml}$ LPS dosage, but response is already very significant with $8 \mu \mathrm{g} / \mathrm{ml}$.

Transcription processes: Proteins such as transcription, initiation and elongation factors and ribonucleoproteins involved at different steps of the transcription process have been also found to be overexpressed in the groups of cells challenged with LPS. This includes elongation factor 1-alpha, elongation factor 1-delta, elongation factor 2, eukariotic initiation factor 4A-1 (EIF4A-1), heterogeneous nuclear ribonucleoprotein $\mathrm{A} 1$ and $60 \mathrm{~S}$ acidic ribosomal protein $\mathrm{P} 2$. For all of them except EIF4A-1 changes in expression are more pronounced for the 16 than for the $8 \mu \mathrm{g} / \mathrm{ml} \mathrm{LPS}$ dosage.

Cell growth/ cell cycle/ proliferation /apoptosis: Differentially expressed proteins involved in these pathways dispatch in up- (78 $\mathrm{kDa}$ glucose-regulated protein, phosphoglycerate kinase 1$)$ and downregulated ones (three different types of metallothioneins (-1, -1A, -2) and galectin-1). Galectin -1 (regulating apoptosis) is downregulated for both LPS dosages whereas the 3 metallothioneins (involved in negative regulation of growth/proliferation) are only up regulated significantly for the 8 $\mu \mathrm{g} / \mathrm{ml}$ LPS dosage.

Immune response:

Histone H2B type 1 (involved in innate immune response in mucosa as a defense mechanism against bacteria) and14 -3-3 protein zeta delta (involved in response proteins from bacterial origin) are strongly upregulated with the $16 \mu \mathrm{g} / \mathrm{ml}$ LPS dosage (no change with 8) whereas alpha enolase (stimulating IgG production, pro-inflammatory and involved in allergy mechanisms) is strongly upregulated with both LPS dosages.

Chromatin / DNA binding proteins:

Histones H2A type 1, H2A.J, H2B type 1-K are more strongly down regulated with the 16 than with $8 \mu \mathrm{g} / \mathrm{ml}$ LPS dosage whereas Histone H4 is more deregulated with 8 . On the contrary, Histone H2B type 1-N, has been found to be upregulated in the LPS16 group.

The whole panel of differentially expressed proteins, their relationships and sense of deregulation has been represented through an interactomic analysis performed with STRING $10^{36}$ (Figure 6). 


\section{Discussion}

LPS used at concentrations in the range of those found from in vivo studies at 72 hours after challenge of bEECs, induce either a strong increase in cell number $(8 \mu \mathrm{g} / \mathrm{ml}$ dosage $)$ or no change in epithelial cell survival $\left(16 \mu \mathrm{g} / \mathrm{ml}\right.$ dosage ${ }^{25}$. These results are in agreement with studies reporting that LPS induced an increase in epithelial cell proliferation from different tissues ${ }^{37-39}$. Differences with results showing an inhibition of epithelial cell number ${ }^{40,41}$ could be partly due to the dosage of LPS that induced an inhibition with the highest LPS dose $(16 \mu \mathrm{g} / \mathrm{ml}$ dosage). However, despite this increase in the number of living cells with a normal morphological appearance, the results of the present study reveal that many changes in protein expression occur following exposure of bEECs to E coli LPS showing that several functions of these cells were highly de-regulated. The consequences of observed changes in protein expression for cell function and possible implications for implantation will be discussed according to the molecular function retrieved from GO annotations.

\section{Structural/Cytoskeleton, calcium metabolism and membrane properties}

Actin and peripherin have been found to be down-regulated with both LPS dosages. These proteins play a key role as structural constituents of cytoskeleton. Such changes in actin remodeling after LPS stimulation have already been described in macrophages and changes in cell mobility have been reported from the same study ${ }^{42}$. The down regulation of actin 2 in this model could also be linked to a rearrangement of other structural proteins following LPS stimuli. This is supported by changes in the regulation of PHB4 and PDIA3 which controls the cleavage and rearrangement of disulfite bounds both inside and outside the cell, modifying proteins attached to cell or nascent proteins.

Annexin A1 and annexin A2 were down-regulated by LPS. They are both involved in calcium metabolism. Annexins are considered as scaffolding proteins which participate in membrane dynamics. In particular, annexin A2, that has structural similarities to annexin A1, has been shown to exhibit anti-inflammatory activities in several animal models of inflammation ${ }^{43-47}$. This protein has been included here in the calcium metabolism proteins because of its calcium binding properties and dependent activity. However, beside these properties in relation with GO annotations, structural activities linked to lipid bilayer and lipid rafts and to actin binding have been reported as well ${ }^{48}$. The regulation of annexins and actin are following the same trend. The anti-inflammatory properties of annexins and the down-regulation observed here are in agreement with the pro-inflammatory role of LPS.

On the contrary, we observed an over-expression of calreticulin which is mainly involved in calcium metabolism and in protein folding (Figure 6). As a chaperone protein, calreticulin is also linked with HSP90. This protein is expressed on the cellular surface and its putative role in cell adhesion, migration or apoptosis has been documented ${ }^{49}$. In addition, calreticulin modulates integrin-dependent $\mathrm{Ca}^{2+}$ signaling [Michalak et al., 1999] and different patterns of expression have been reported during implantation in mice [Cheng et al., 2009].This protein is expressed on the cellular surface and its putative role in cell adhesion, migration or apoptosis has been documented ${ }^{49}$. In addition, calreticulin modulates integrin-dependent $\mathrm{Ca}^{2+}$ signaling ${ }^{50}$ and different patterns of expression have been reported during implantation in mice ${ }^{51}$. The signification of its overexpression in our model in relation with the above still has to be elucidated.

The full mechanism by which LPS provokes these changes remains to be deciphered. However, our results suggest that LPS destabilizes cell structure and modify cell membrane properties in a way cell adhesion is reduced. To our knowledge, the possible roles of LPS in altering such functions have not been much described before especially in relation with implantation. The changes observed could be of considerable importance while considering the role of adhesion molecules and membrane function in this process. 
Another response to LPS in relation with cell structure could be part of a defense mechanism contributing to inhibit protease activity through down-regulation of the protease cathepsin and upregulation of the peptidase inhibitor Cystatin-B. As Cystatin-B is an inhibitor of cathepsin protease, the trend of expression of these two proteins is consistent and such changes may protect cells from proteolytic activity. The role of this anti-protease mechanism and its relation with the changes reported above in cell structure and membrane permeability requires further investigation.

\section{Energy Metabolism}

Differentially expressed proteins related to energy metabolism proteins were all found to be overexpressed in both LPS groups when compared to controls. These proteins are mostly glycolytic proteins as Phosphoglycerate mutase, Glyceraldehyde-3-phosphate dehydrogenase, Triosephosphate isomerase, Beta-enolase OS and Alpha-enolase. The interactomic analysis (Figure 6) shows clearly that energy metabolism occupies a very central place in this system. This is consistent with the fact that LPS induced glycolysis which has been constantly reported in literature from other tissues and other species ${ }^{52-54}$ determines other cell responses thus contributing in many ways to the development of pathological processes.

Oxidative stress response

Even if this in vitro model is working outside the in vivo machinery and based on a single population of cells, many proteins involved in this pathway and in protection from oxidative stress are deregulated showing the key role of LPS while inducing oxidative stress. They occupy a place close to proteins involved in metabolism (Figure 6) and most of them may result from LPS induced glycolysis changes. The only protein that is not linked with other proteins, in this interactomic analysis, is the SH3 domain-binding glutamic acid-rich-like protein 3 that, according to GO classification, was related to cell redox homeostasis and is also involved in regulation of actin cytoskeleton organization. Interestingly, our results confirm also the up-regulation of Peroxiredoxin-1, which has been described as a strong promoter of inflammation through stimulation of the synthesis of proinflammatory cytokines such as interleukin-6 (IL-6), interleukin-8 (IL-8), and tumor necrosis factor- $\alpha(\mathrm{TNF}-\alpha)^{55}$.

Changes in cytokines were not evidenced from this epithelial cells model. However, the up-regulation of Peroxiredoxin-1 and other pro-inflammatory molecules such as Enolases may represent an important link between LPS stimulation and the generation of inflammatory cascade in surrounding cells.

Translation Process/protein synthesis, regulation of cell cycle and proliferation

As for the energy metabolism, several proteins involved in protein biosynthesis such as initiation and elongation factors have been found to be strongly up-regulated. This demonstrates that the translation machinery is stimulated by LPS. The strong links between these proteins in the interactome and their upregulation is very consistent with the role of this family of factors in the stimulation of cell growth and proliferation ${ }^{56,57}$ and the present changes in this phenotype induced by LPS. In addition to the above, other proteins have been reported, from their GO annotated molecular functions, to be related with regulation of cell cycle and cell proliferation. In this case, the interpretation of the interactomic analysis is more complex than for other functions. A strong link was found, with a high significant value, between Transketolase, Phosphoglycerate kinase 1 and $78 \mathrm{kDa}$ glucose-regulated protein, the latest being linked to the above translation machinery. From GO molecular functions, all these proteins are involved in regulation of cellular growth, epithelial cells differentiation and act as positive regulators of cell migration. As for proteins involved in translation their up-regulation is consistent with the proliferative phenotype observed following LPS challenge.

No links were found between the above and metallothioneins nor galectin-1. Metallothioneins were found here to be up-regulated only in cells exposed to $8 \mu \mathrm{g} / \mathrm{ml}$ LPS and galectin- 1 is down regulated 
for both LPS dosages. These proteins are classified, from GO annotated molecular functions, as involved in negative regulation of growth. The up-regulation of metallothioneins looks in contrast with the growing phenotype observed in our model. However, their up-regulation could be related to a compensatory mechanism from cells to counteract the proliferative response induced by the activation of metabolism and transcription machinery. This response could be also associated to different functions as these proteins have been reported to be involved in bactericidal activity and nitric oxide production following LPS stimulation ${ }^{58}$.

Immune response; relationships with establishment of pregnancy

Our results showing that 14-3-3 protein zeta/delta is up-regulated in the LPS16 group versus control group is consistent with former functions of this protein described in literature. It's major role in the regulation of corneal epithelial proliferation and differentiation in corneal mice cell culture has been reported ${ }^{59}$. This protein has been shown to be also involved in the regulation of the production of cytokines ${ }^{60}$ and, the gamma proteoform, is up-regulated during LPS-induced cardiomyocytes injury ${ }^{61}$. Its major role in Toll-like receptors activation has also been demonstrated and its involvement in the lipopolysaccharide-induced production of tumor necrosis factor by macrophages has been documented ${ }^{62}$. A recent study demonstrated that $14-3-3 \gamma$ was able to attenuate the LPS-induced inflammatory responses and to induce the proliferation of dairy cow mammary epithelial cells ${ }^{63}$. The up-regulation of this protein we observed may be part of a similar anti-inflammatory mechanism taking place in our model in response to LPS.

One of the most interesting finding in our results in relation with establishment of pregnancy is the strong down-regulation of galectin-1 induced by LPS. To our knowledge this has not been reported before. Galectin-1 has been mostly studied in human and rodents and has been shown to be expressed in the bovine endometrium ${ }^{64}$. In the human, this protein is abundantly expressed in the non-immune cells at the fetus-maternal interface, down regulates the production of pro-inflammatory cytokines and promotes maternal immune tolerance ${ }^{65}$. In the mouse, Yakushina et al., $2015^{66}$ shown that galectin-1 stimulates the differentiation of $\mathrm{CD} 4+$ cells into T-regulatory cells then being one of the key molecules involved in immune-tolerance. Probably as the result of the above, low expression in the endometrium has been associated to an increased frequency of early pregnancy failures and miscarriages ${ }^{67,68}$.

As part of the metabolic changes both $\alpha$ and $\beta$-enolase are both up-regulated following challenges with similar responses for both LPS dosages. Among other roles, $\alpha$ - enolase has been reported as an allergenic molecule with immune and strong pro-inflammatory properties ${ }^{69-71}$. In rats, high expression of $\alpha$-enolase has been associated with increased numbers of CD4 $+\mathrm{T}$ cells and immuno rejection in an allograft transplantation model $^{72}$.

The impact of immune imbalance induced by deregulations of galectin- 1 and $\alpha$-enolase on the establishment of pregnancy has to be demonstrated in the bovine through functional studies. If existing and persistent, the lack of immunosuppression induced by LPS through down regulation of galectin-1 and up-regulation of pro-inflammatory processes through enolases could be part of the mechanisms altering implantation success even in the absence of bacterial infection.

\section{Chromatin and DNA binding}

A differential expression of several DNA binding proteins such as histones has been found. As said before for other processes, the interactome picture is quite complex here with 4 of them under expressed and 2 over expressed following LPS challenge and more specific work is needed to decipher the mechanisms explaining the overexpression of some specific histones and the downregulation of some other isoforms. However, from the 4 histones under expressed we found 2 (Histone H2A type1 and H2AJ) which are associated with chromatin silencing consistent with the over expression of many pathways. The over expression of Histones H2B type1 and H2B type1N following exposure to the $16 \mu \mathrm{g} / \mathrm{ml}$ dosage is also consistent with their roles in innate immune 
response in mucosa and DNA protein binding. Effectively, some histones, such as H2B type1, could represent LPS binding proteins ${ }^{73}$ and their differential expression could contribute to the formation of an antimicrobial and of an endotoxin-neutralizing barrier against microorganisms ${ }^{74}$.

\section{Conclusion}

This study shows that many pathways involved in a wide range of functions are affected by LPS. Some were awaited, and the corresponding changes in mRNAs and proteins described. However, even for these pathways which have been studied intensively and largely documented, such as the immune response, this proteomic approach reveals that deregulation occurs for specific molecules which have not been described in former studies and /or not related to the role of LPS and its possible impacts on the establishment of pregnancy. Taken together, the results from this cow model based on a pure population of epithelial cells provide evidence that LPS induces the activation of proinflammatory mechanisms and at the same time down regulates signals reported to be involved in immune-tolerance in other species (such as Galectin-1). The persistence of changes possibly induced by LPS due to exposure to pathogens during the post-partum period and their subsequent implication in fertility failures at time of establishment of pregnancy deserves further investigations.

\section{Aknoledgments}

This work was performed with the financial support of the EU project "PROLIFIC" (grant KBBE 311776-PR and PH) and of Rajamangala University of Technology Srivijaya (RMUTSV, Thailand).

\section{References}

1. A. Barbat, P. L. MÉZEC, V. Ducrocq, S. Mattalia, S. Fritz, D. Boichard, C. Ponsart and P. Humblot, Journal of Reproduction and Development, 2010, 56, S15-S21.

2. M. Royal, A. Darwash, A. Flint, R. Webb, J. Woolliams and G. Lamming, Animal science, 2000, 70, 487-501.

3. J. Pryce, M. Royal, P. Garnsworthy and I. L. Mao, Livestock Production Science, 2004, 86, $125-$ 135.

4. B. Grimard, S. Freret, A. Chevallier, A. Pinto, C. Ponsart and P. Humblot, Animal reproduction science, 2006, 91, 31-44.

5. I. M. Sheldon, J. Cronin, L. Goetze, G. Donofrio and H.-J. Schuberth, Biology of reproduction, 2009, 81, 1025-1032. 
6. R. O. Gilbert, S. T. Shin, C. L. Guard, H. N. Erb and M. Frajblat, Theriogenology, 2005, 64, 1879-1888.

7. T. J. Potter, J. Guitian, J. Fishwick, P. J. Gordon and I. M. Sheldon, Theriogenology, 2010, 74, 127-134.

8. D. G. Morris, S. M. Waters, S. D. McCarthy, J. Patton, B. Earley, R. Fitzpatrick, J. J. Murphy, M. G. Diskin, D. A. Kenny and A. Brass, Physiological genomics, 2009, 39, 28-37.

9. P. Humblot, B. Grimard, S. Freret, G. Charpigny, A. Ponter, H. Seegers, C. Ponsart, P. Garnsworthy and J. Wiseman, 2009.

10. D. Valour, I. Hue, S. Degrelle, S. Déjean, G. Marot, O. Dubois, G. Germain, P. Humblot, A. Ponter and G. Charpigny, Reproduction in Domestic Animals, 2013, 48, 484-499.

11. L. Elliott, K. McMahon, H. Gier and G. Marion, American journal of veterinary research, 1968, 29, 77.

12. I. Sheldon, D. Noakes, A. Rycroft, D. Pfeiffer and H. Dobson, Reproduction, 2002, 123, 837845.

13. E. J. Williams, D. P. Fischer, D. E. Noakes, G. C. England, A. Rycroft, H. Dobson and I. M. Sheldon, Theriogenology, 2007, 68, 549-559.

14. G. Donofrio, L. Ravanetti, S. Cavirani, S. Herath, A. Capocefalo and I. M. Sheldon, Reproduction, 2008, 136, 361-366.

15. L. Mateus, L. L. da Costa, P. Diniz and A. Ziecik, Animal reproduction science, 2003, 76, 143154.

16. J. G. Cronin, M. L. Turner, L. Goetze, C. E. Bryant and I. M. Sheldon, Biology of reproduction, 2012, 86, 51.

17. S. Herath, S. T. Lilly, N. R. Santos, R. O. Gilbert, L. Goetze, C. E. Bryant, J. O. White, J. Cronin and I. M. Sheldon, Reproductive Biology and Endocrinology, 2009, 7, 55.

18. Y. Wang, C. Wang, Z. Hou, K. Miao, H. Zhao, R. Wang, M. Guo, Z. Wu, J. Tian and L. An, Journal of animal science and biotechnology, 2013, 4, 39.

19. E. J. Verspohl and J. Podlogar, 2012.

20. C. Fischer, M. Drillich, S. Odau, W. Heuwieser, R. Einspanier and C. Gabler, Reproduction, Fertility and Development, 2010, 22, 818-829.

21. C. F. Oguejiofor, Z. Cheng, A. Abudureyimu, O. L. Anstaett, J. Brownlie, A. A. Fouladi-Nashta and D. C. Wathes, Biology of reproduction, 2015, biolreprod. 115.128876.

22. C. Choe, J.-W. Park, E.-S. Kim, S.-G. Lee, S.-Y. Park, J.-S. Lee, M.-J. Cho, K. R. Kang, J. Han and

D. Kang, The Korean Journal of Physiology \& Pharmacology, 2010, 14, 205-212. 
23. M. Chanrot, Y. Guo, A. Dalin, E. Persson, R. Bage, A. Svensson, H. Gustafsson and P. Humblot, Animal Reproduction Science, 2016.

24. M. Dohmen, K. Joop, A. Sturk, P. Bols and J. Lohuis, Theriogenology, 2000, 54, 1019-1032.

25. Y. Guo, M. Chanrot, P. Reinaud, G. Charpigny, O. Sandra, J.-F. Valarcher and P. Humblot, Reproduction, Fertility and Development, 2013, 26, 165-166.

26. C. Piras, A. Soggiu, L. Bonizzi, A. Gaviraghi, F. Deriu, L. De Martino, G. lovane, A. Amoresano and P. Roncada, Molecular BioSystems, 2012, 8, 1060-1067.

27. C. Piras, A. Soggiu, L. Bonizzi, V. Greco, M. Ricchi, N. Arrigoni, A. Bassols, A. Urbani and P. Roncada, Proteomics, 2015, 15, 813-823.

28. C. Piras, A. Soggiu, V. Greco, A. Cassinotti, G. Maconi, S. Ardizzone, A. Amoresano, G. B. Porro, L. Bonizzi and P. Roncada, EuPA Open Proteomics, 2014, 3, 48-59.

29. A. Shevchenko, H. Tomas, J. Havli, J. V. Olsen and M. Mann, Nature protocols, 2006, 1, 28562860 .

30. C. Piras, A. Soggiu, V. Greco, P. A. Martino, F. Del Chierico, L. Putignani, A. Urbani, J. E. Nally, L. Bonizzi and P. Roncada, Journal of proteomics, 2015, 127, 365-376.

31. M. De Canio, A. Soggiu, C. Piras, L. Bonizzi, A. Galli, A. Urbani and P. Roncada, Molecular BioSystems, 2014, 10, 1264-1271.

32. A. Soggiu, C. Piras, H. A. Hussein, M. De Canio, A. Gaviraghi, A. Galli, A. Urbani, L. Bonizzi and P. Roncada, Molecular BioSystems, 2013, 9, 1188-1195.

33. H. Mi, S. Poudel, A. Muruganujan, J. T. Casagrande and P. D. Thomas, Nucleic acids research, 2016, 44, D336-342.

34. J. P. Vissers, J. I. Langridge and J. M. Aerts, Molecular \& Cellular Proteomics, 2007.

35. J. C. Silva, M. V. Gorenstein, G.-Z. Li, J. P. Vissers and S. J. Geromanos, Molecular \& Cellular Proteomics, 2006, 5, 144-156.

36. D. Szklarczyk, A. Franceschini, S. Wyder, K. Forslund, D. Heller, J. Huerta-Cepas, M. Simonovic, A. Roth, A. Santos, K. P. Tsafou, M. Kuhn, P. Bork, L. J. Jensen and C. von Mering, Nucleic acids research, 2015, 43, D447-452.

37. L. Liu, Y. H. Li, Y. B. Niu, Y. Sun, Z. J. Guo, Q. Li, C. Li, J. Feng, S. S. Cao and Q. B. Mei, Carcinogenesis, 2010, 31, 1822-1832.

38. K. Piotrowska-Tomala, M. Siemieniuch, A. Szóstek, A. Korzekwa, I. Woclawek-Potocka, A. Galváo, K. Okuda and D. Skarzynski, Domestic animal endocrinology, 2012, 43, 278-288.

39. M. Eslani, A. Movahedan, N. Afsharkhamseh, H. Sroussi and A. R. Djalilian, Investigative ophthalmology \& visual science, 2014, 55, 6108-6115.

40. A. Freitag, A. Reimann, I. Wessler and K. Racké, Pulmonary pharmacology, 1996, 9, 149-156. 
41. Z. Hei, A. Zhang, J. Wei, X. Gan, Y. Wang, G. Luo and X. Li, Journal of Trauma and Acute Care Surgery, 2012, 73, 67-72.

42. G. Kleveta, K. Borzęcka, M. Zdioruk, M. Czerkies, H. Kuberczyk, N. Sybirna, A. Sobota and K. Kwiatkowska, Journal of cellular biochemistry, 2012, 113, 80-92.

43. S. Zhang, M. Yu, Q. Guo, R. Li, G. Li, S. Tan, X. Li, Y. Wei and M. Wu, Scientific reports, 2014, 5, 15859-15859.

44. R. Hannon, J. D. Croxtall, S. J. GETTING, F. ROVIEZZO, S. Yona, M. J. Paul-Clark, F. N. Gavins, M. Perretti, J. F. Morris and J. C. Buckingham, The FASEB Journal, 2003, 17, 253-255.

45. M. Perretti and F. D'Acquisto, Nature Reviews Immunology, 2009, 9, 62-70.

46. J. Dalli, L. V. Norling, D. Renshaw, D. Cooper, K.-Y. Leung and M. Perretti, Blood, 2008, 112, 2512-2519.

47. X. Fan, S. Krahling, D. Smith, P. Williamson and R. A. Schlegel, Molecular biology of the cell, $2004,15,2863-2872$.

48. M. J. Hayes, U. Rescher, V. Gerke and S. E. Moss, Traffic, 2004, 5, 571-576.

49. Y. Jiang, S. Dey and H. Matsunami, Membranes, 2014, 4, 630-641.

50. M. Michalak, E. F. Corbett, N. Mesaeli, K. Nakamura and O. Michal, Biochemical Journal, 1999, 344, 281-292.

51. S.-Q. Cheng, J.-L. He, Y.-L. Dong, X.-Q. Liu, Y.-B. Ding, R.-F. Gao, Y. Tan, Q. Ye, Z.-L. Tian and Y.-X. Wang, Biological research, 2009, 42, 505-516.

52. N. Silanikove, A. Rauch-Cohen, F. Shapiro, S. Blum, A. Arieli and G. Leitner, Journal of dairy science, 2011, 94, 4468-4475.

53. R. Garcia-Carbonell, A. S. Divakaruni, A. Lodi, I. Vicente-Suarez, A. Saha, H. Cheroutre, G. R. Boss, S. Tiziani, A. N. Murphy and M. Guma, Arthritis \& Rheumatology, 2016.

54. H. Sun, Y. Huang, C. Yin, J. Guo, R. Zhao and X. Yang, Animal: an international journal of animal bioscience, 2016, 1-9.

55. D. Liu, P. Mao, Y. Huang, Y. Liu, X. Liu, X. Pang and Y. Li, Mediators of inflammation, 2014, 2014.

56. D. Shahbazian, A. Parsyan, E. Petroulakis, I. Topisirovic, Y. Martineau, B. F. Gibbs, Y. Svitkin and N. Sonenberg, Molecular and cellular biology, 2010, 30, 1478-1485.

57. E. Long, A. Lazaris-Karatzas, C. Karatzas and X. Zhao, The international journal of biochemistry \& cell biology, 2001, 33, 133-141.

58. N. Itoh, H. Shibayama, M. Kanekiyo, D. Namphung, T. Nakanishi, A. Matsuyama, T. Odani and K. Tanaka, Toxicology, 2005, 216, 188-196. 
59. Y. Xin, Q. Lu and Q. Li, Biochemical and biophysical research communications, 2010, 392, 593-598.

60. T. Hochdörfer, C. Tiedje, D. J. Stumpo, P. J. Blackshear, M. Gaestel and M. Huber, Cellular signalling, 2013, 25, 1339-1347.

61. D. Liu, B. Yi, Z. Liao, L. Tang, D. Yin, S. Zeng, J. Yao and M. He, International immunopharmacology, 2014, 21, 509-515.

62. A. Ben-Addi, A. Mambole-Dema, C. Brender, S. R. Martin, J. Janzen, S. Kjaer, S. J. Smerdon and S. C. Ley, Proceedings of the National Academy of Sciences, 2014, 111, E2394-E2403.

63. L. Liu, Y. Lin, L. Liu, Y. Bian, L. Zhang, X. Gao and Q. Li, International journal of molecular sciences, 2015, 16, 16622-16641.

64. R. Froehlich, N. Hambruch, J.-D. Haeger, M. Dilly, H. Kaltner, H.-J. Gabius and C. Pfarrer, Placenta, 2012, 33, 195-201.

65. F. Gómez-Chávez, V. Castro-Leyva, A. Espejel-Núñez, R. G. Zamora-Mendoza, H. RosasVargas, J. C. Cancino-Díaz, M. E. Cancino-Díaz, G. Estrada-Gutierrez and S. RodríguezMartínez, Journal of reproductive immunology, 2015, 112, 46-52.

66. V. Yakushina, O. Vasil'eva, N. Ryazantseva, V. Novitsky and L. Tashireva, Molecular and cellular biochemistry, 2015, 398, 245-249.

67. U. Jeschke, B. Toth, C. Scholz, K. Friese and A. Makrigiannakis, Journal of reproductive immunology, 2010, 85, 99-105.

68. G. Barrientos, N. Freitag, I. Tirado-González, L. Unverdorben, U. Jeschke, V. L. Thijssen and S. M. Blois, Human reproduction update, 2014, 20, 175-193.

69. M. Bruschi, R. A. Sinico, G. Moroni, F. Pratesi, P. Migliorini, M. Galetti, C. Murtas, A. Tincani, M. Madaio and A. Radice, Journal of the American Society of Nephrology, 2014, 25, 24832498.

70. K. Ozyurt, A. Çelik, M. Sayarlıoglu, E. Colgecen, R. Incı, T. Karakas, M. Kelles and G. Y. Cetin, Journal of Oral Pathology \& Medicine, 2014, 43, 691-695.

71. J. S. Maier-Moore, K. A. Koelsch, K. Smith, C. J. Lessard, L. Radfar, D. Lewis, B. T. Kurien, N. Wolska, U. Deshmukh and A. Rasmussen, Arthritis \& Rheumatology, 2014, 66, 3445-3456.

72. J. Shi, Y. Li, X. Yang, D. Yang, Y. Zhang and Y. Liu, Pediatric transplantation, 2014, 18, 575585.

73. L. A. Augusto, P. Decottignies, M. Synguelakis, M. Nicaise, P. Le Maréchal and R. Chaby, Biochemistry, 2003, 42, 3929-3938.

74. H. S. Kim, J. H. Cho, H. W. Park, H. Yoon, M. S. Kim and S. C. Kim, The Journal of Immunology, 2002, 168, 2356-2364. 


\section{Figure legends}

Figure 1: Strategy for the proteomic analyses. Left part of graph 2D Electrophoresis and Maldi TOF TOF. All cell pellets from 9 cows ( 3 samples per cow, Control CTRL and LPS treated cells; LPS 8 $\mu \mathrm{g} / \mathrm{ml}$, LPS $16 \mu \mathrm{g} / \mathrm{ml}$ ) were analyzed following separation of protein spots by 2D gel electrophoresis and identification of spots by image analysis (Progenesis), gel spots were digested and then differentially expressed (DE) proteins identified by MALDI TOF-TOF MS (Ultraflex III, Bruker) and quantified. Right part nLC-MS/MS analysis was performed in the first series of three cows (3 samples per cow as above) peptide separation and identification was done following tryptic digestion of total protein extracts. Assays were run in triplicate for each sample in each type of analysis.

Figure 2: Representative image of 2D map of one biological replicate.

Figure 3: Differentially expressed proteins observed from 2D electrophoresis followed by MALDI TOF TOF MS analysis in response to LPS (CTRL Control, LPS $8 \mu \mathrm{g} / \mathrm{ml}$, LPS $16 \mu \mathrm{g} / \mathrm{ml}$ ). For each bar is reported the mean \pm SD value of nine biological replicates $(n=9)$. Proteins follow the survival profile of epithelial cells (PDIA3 Protein Disulfide Isomerase) or is inverse (ANXA2 Annexin 2). Significance $\left(* \mathrm{p}<0.05,{ }^{* *} \mathrm{p}<0.01\right)$ indicates differential expression between treated samples and controls.

Figure 4: Mean response for 5 differentially expressed proteins following 3 series of LPS challenge with 8 and $16 \mu \mathrm{g} / \mathrm{ml}$ LPS (each bar from 9 individual cows). Results are expressed as ratios when compared to controls and for each LPS dosage, significance of differences are tested against 0 ; * $\mathrm{p}<0.05, * * \mathrm{p}<0.01, * * * \mathrm{p}<0.001$. For all proteins, differences between 8 and $16 \mu \mathrm{g} / \mathrm{ml}$ LPS are nonsignificant.

Figure 5: Results from shotgun analysis, proteins significantly overexpressed and under-expressed following challenge of endometrial epithelial cells with 8 (orange bars) or $16 \mu \mathrm{g} / \mathrm{ml} \mathrm{LPS} \mathrm{(grey} \mathrm{bars)}$ when compared to controls (blue bars), ${ }^{*} \mathrm{p}<0.05,{ }^{*} \mathrm{p}<0.01$.

Figure 6. Protein legend STRING protein-protein interaction analysis. The string name of each protein represented in the figure is indicated in the $4^{\text {th }}$ column of table 1. 


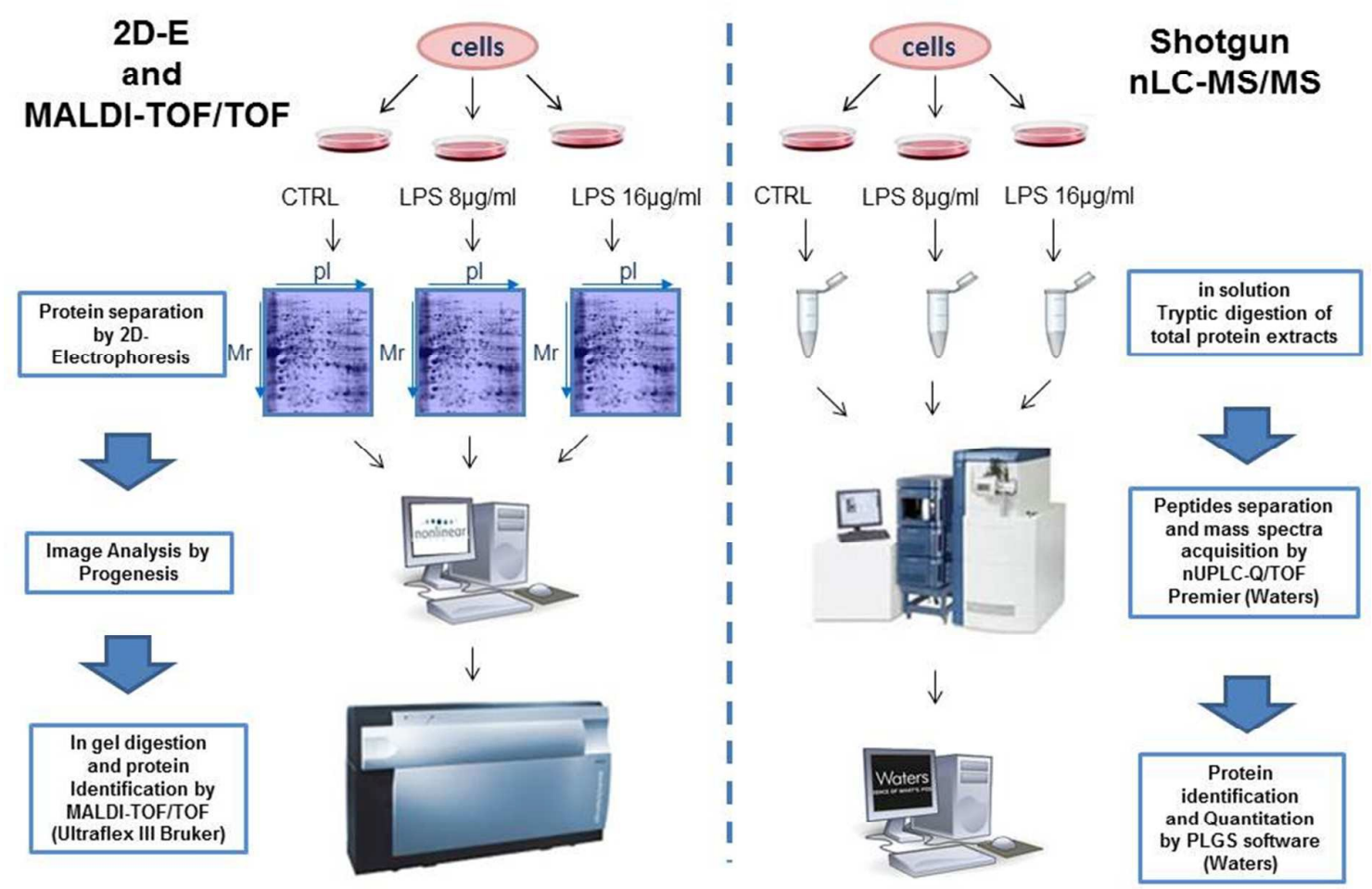

Figure 1: Strategy for the proteomic analyses. Left part of graph 2D Electrophoresis and Maldi TOF TOF. All cell pellets from 9 cows $(3$ samples per cow, Control CTRL and LPS treated cells; LPS $8 \mu \mathrm{g} / \mathrm{ml}$, LPS $16 \mu \mathrm{g} / \mathrm{ml}$ ) were analyzed following separation of protein spots by 2D gel electrophoresis and identification of spots by image analysis (Progenesis), gel spots were digested and then differentially expressed (DE) proteins identified by MALDI TOF-TOF MS (Ultraflex III, Bruker) and quantified. Right part nLC-MS/MS analysis was performed in the first series of three cows ( 3 samples per cow as above) peptide separation and identification was done following tryptic digestion of total protein extracts. Assays were run in triplicate for each sample in each type of analyse. 


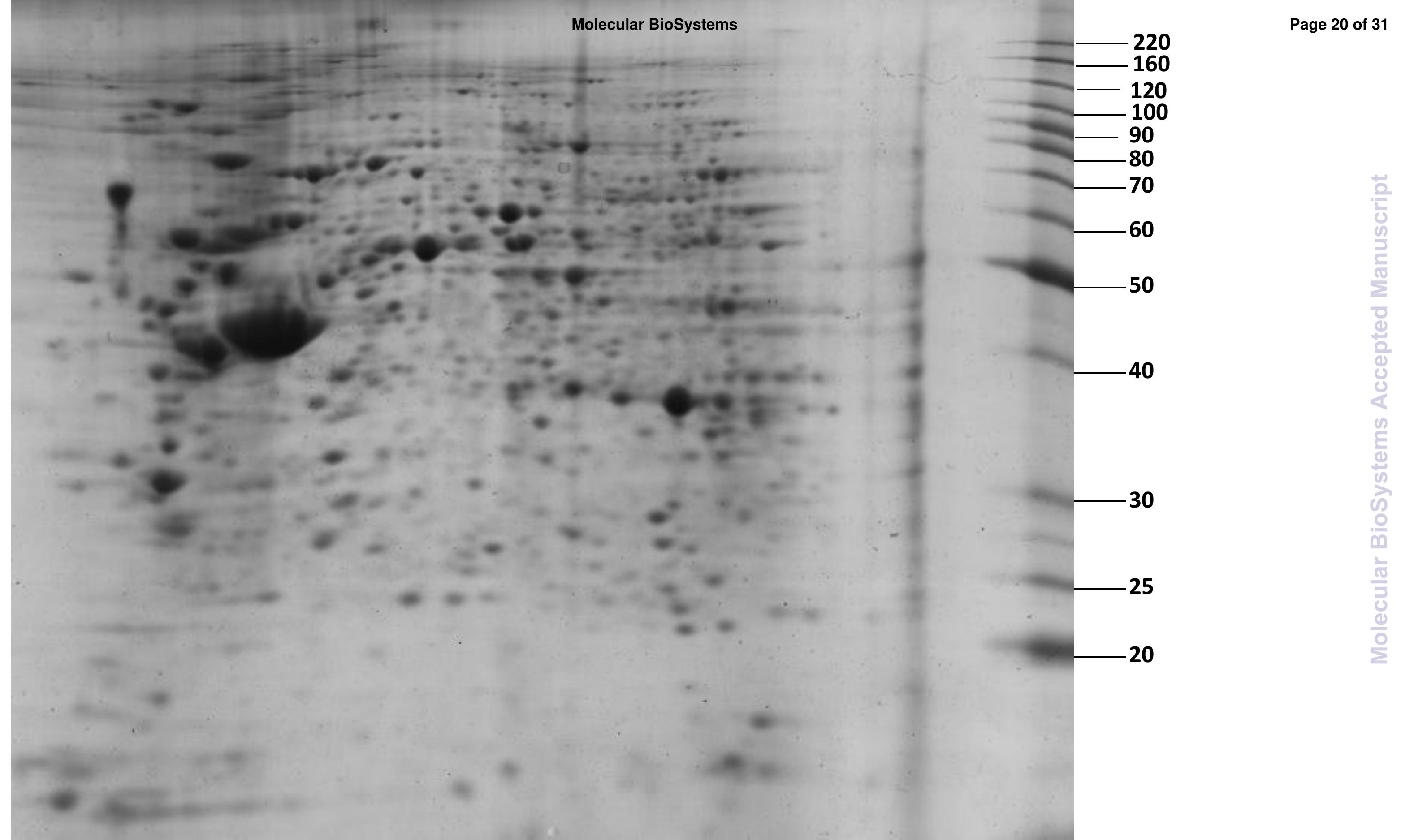




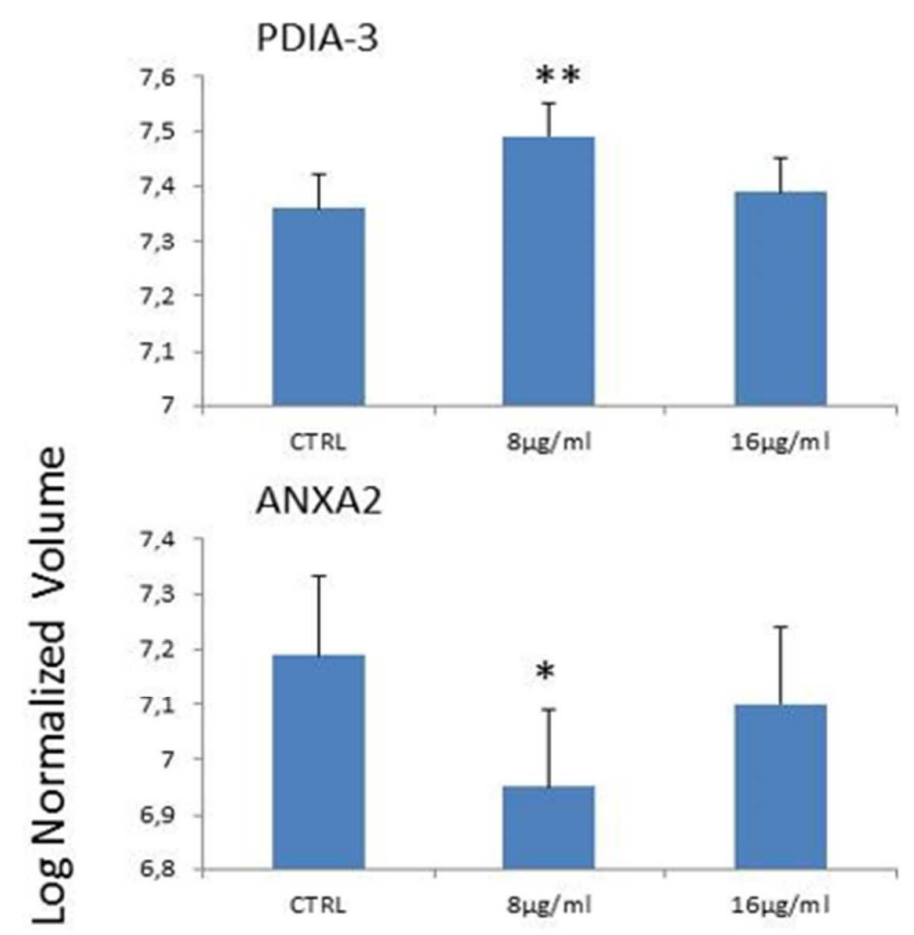

Figure 3: Differentially expressed proteins observed from 2D electrophoresis followed by MALDI TOF TOF MS analysis in response to LPS (CTRL Control, LPS $8 \mu \mathrm{g} / \mathrm{ml}$, LPS $16 \mu \mathrm{g} / \mathrm{ml})$. For each bar is reported the mean \pm SD value of nine biological replicates $(n=9)$. Proteins follow the survival profile of epithelial cells (PDIA3 Protein Disulfide Isomerase) or is inverse (ANXA2 Annexin 2). Significance $(* \mathrm{p}<0.05, * * p<0.01)$ indicates differential expression between treated samples and controls. 


\section{Annexin-2}
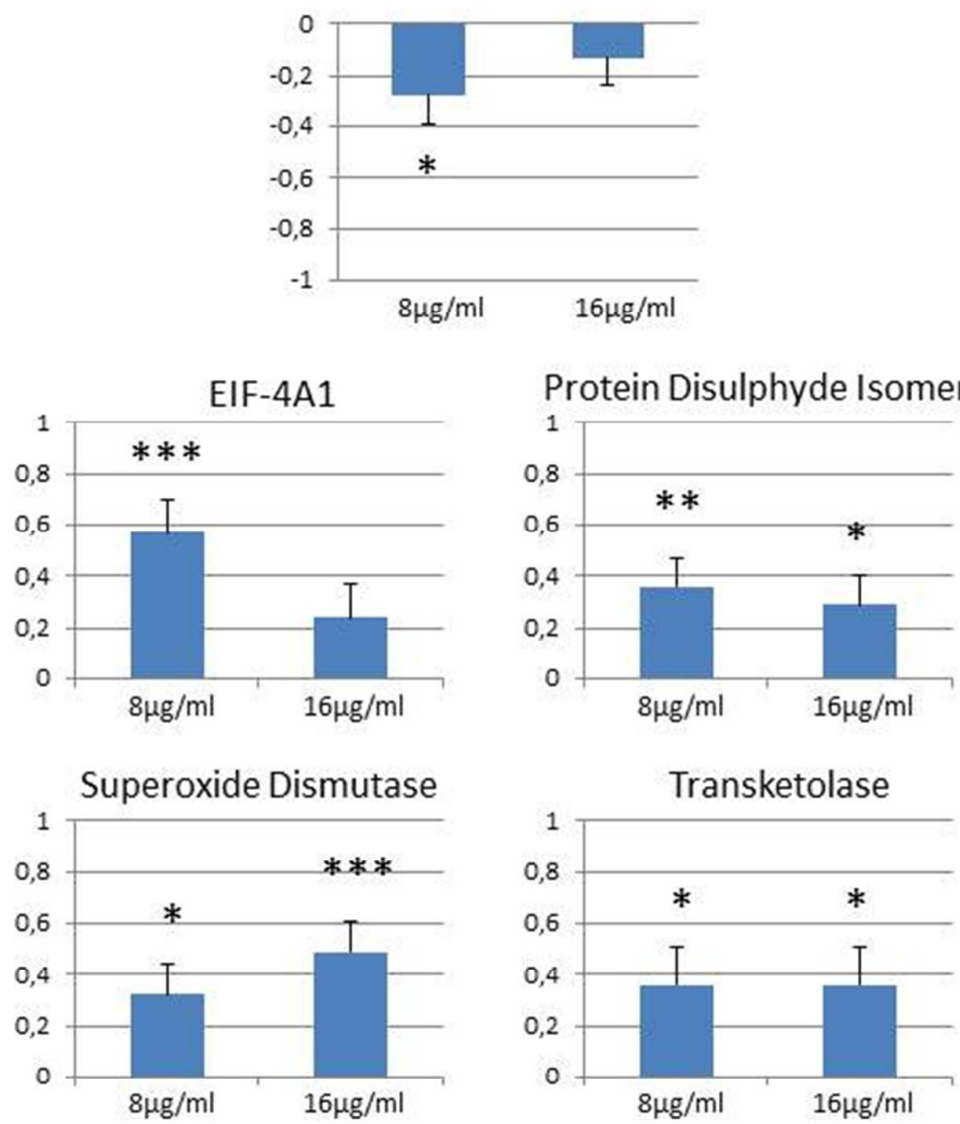

Figure 4: Mean response for 5 differentially expressed proteins following 3 series of LPS challenge with 8 and $16 \mu \mathrm{g} / \mathrm{ml}$ LPS (each bar from 9 individual cows). Results are expressed as ratios when compared to controls and for each LPS dosage, significance of differences are tested against $0 ; * \mathrm{p}<0.05, * * \mathrm{p}<0.01, * * * \mathrm{p}<0.001$. For all proteins, differences between 8 and $16 \mu \mathrm{g} / \mathrm{ml}$ LPS are non-significant. 


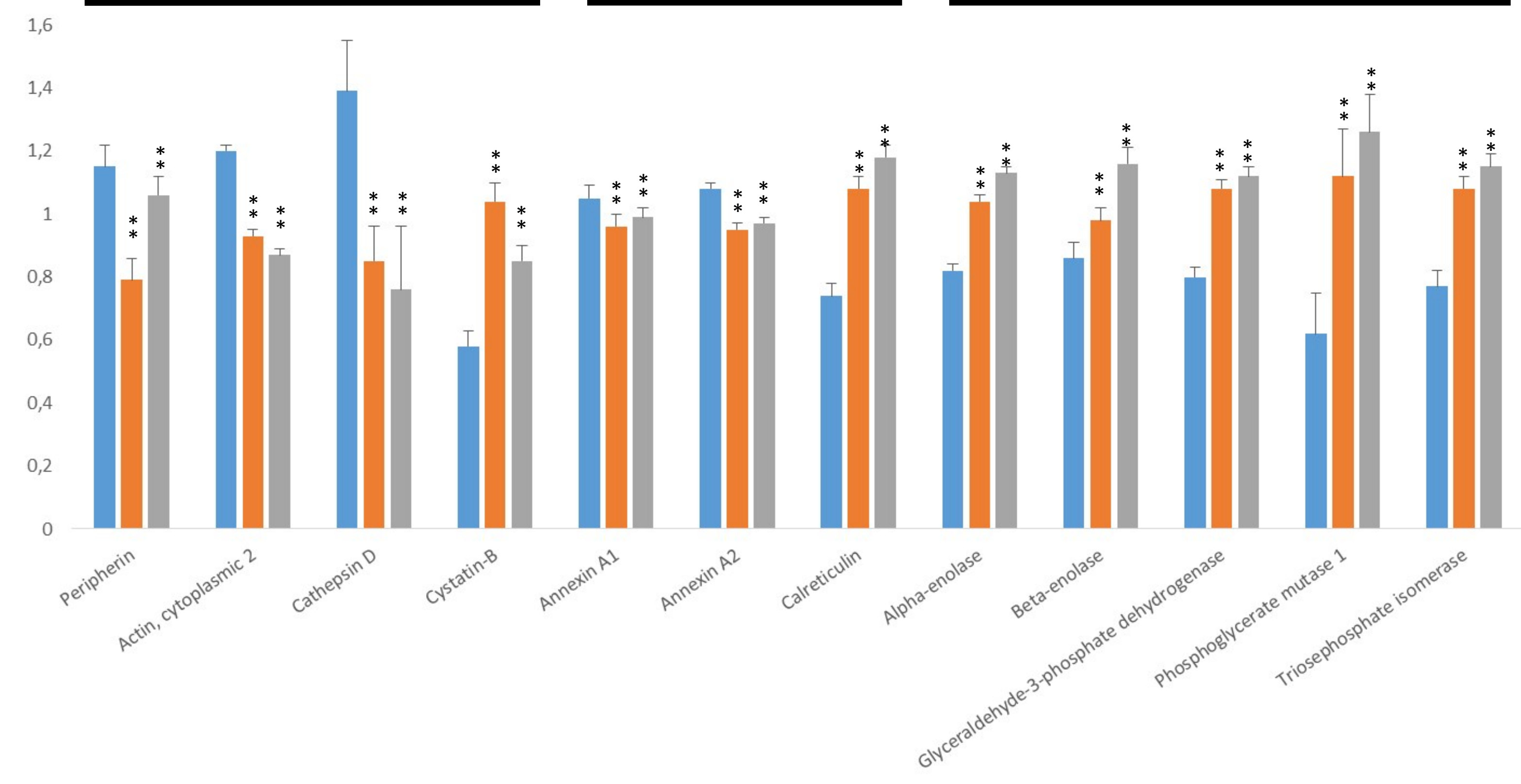




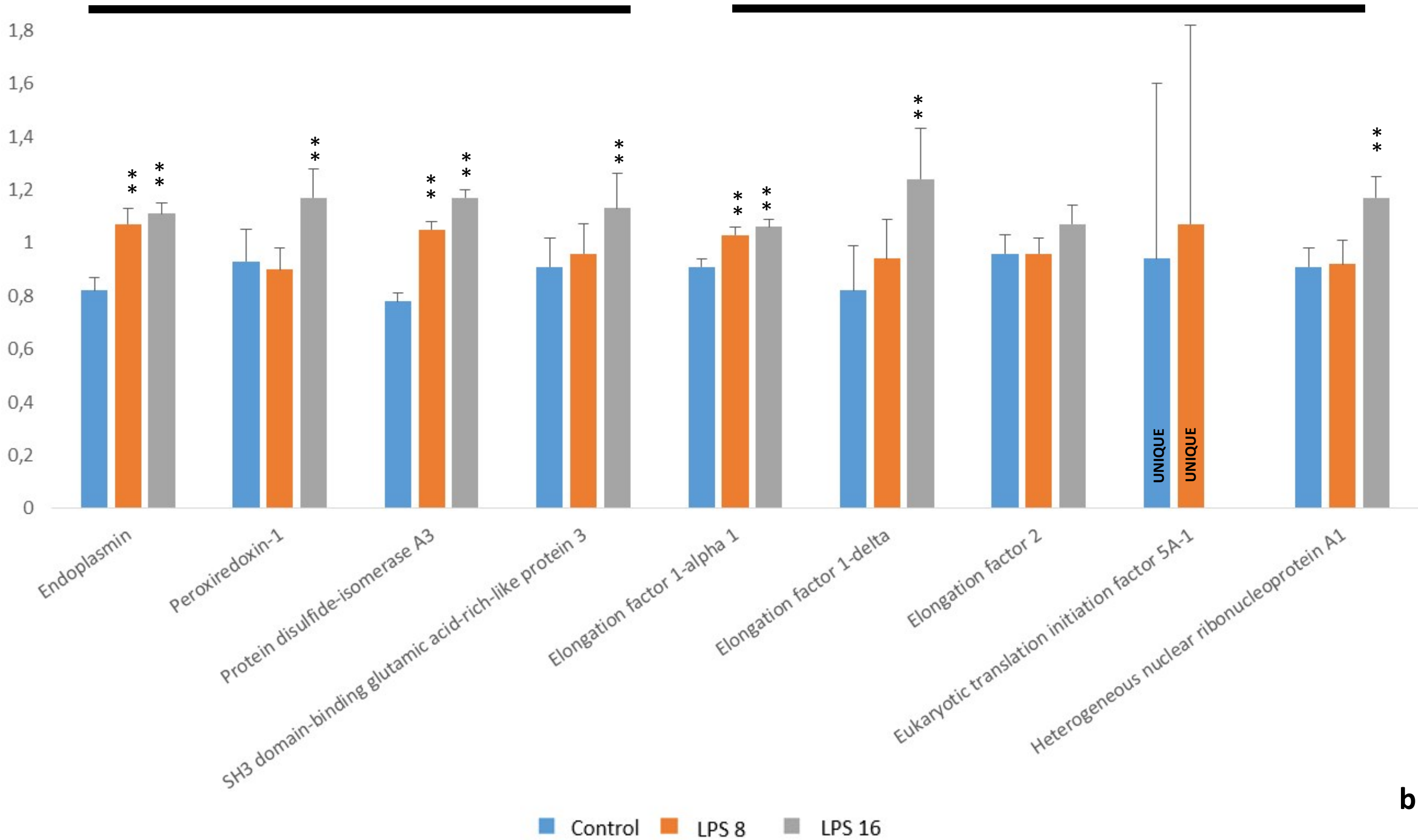




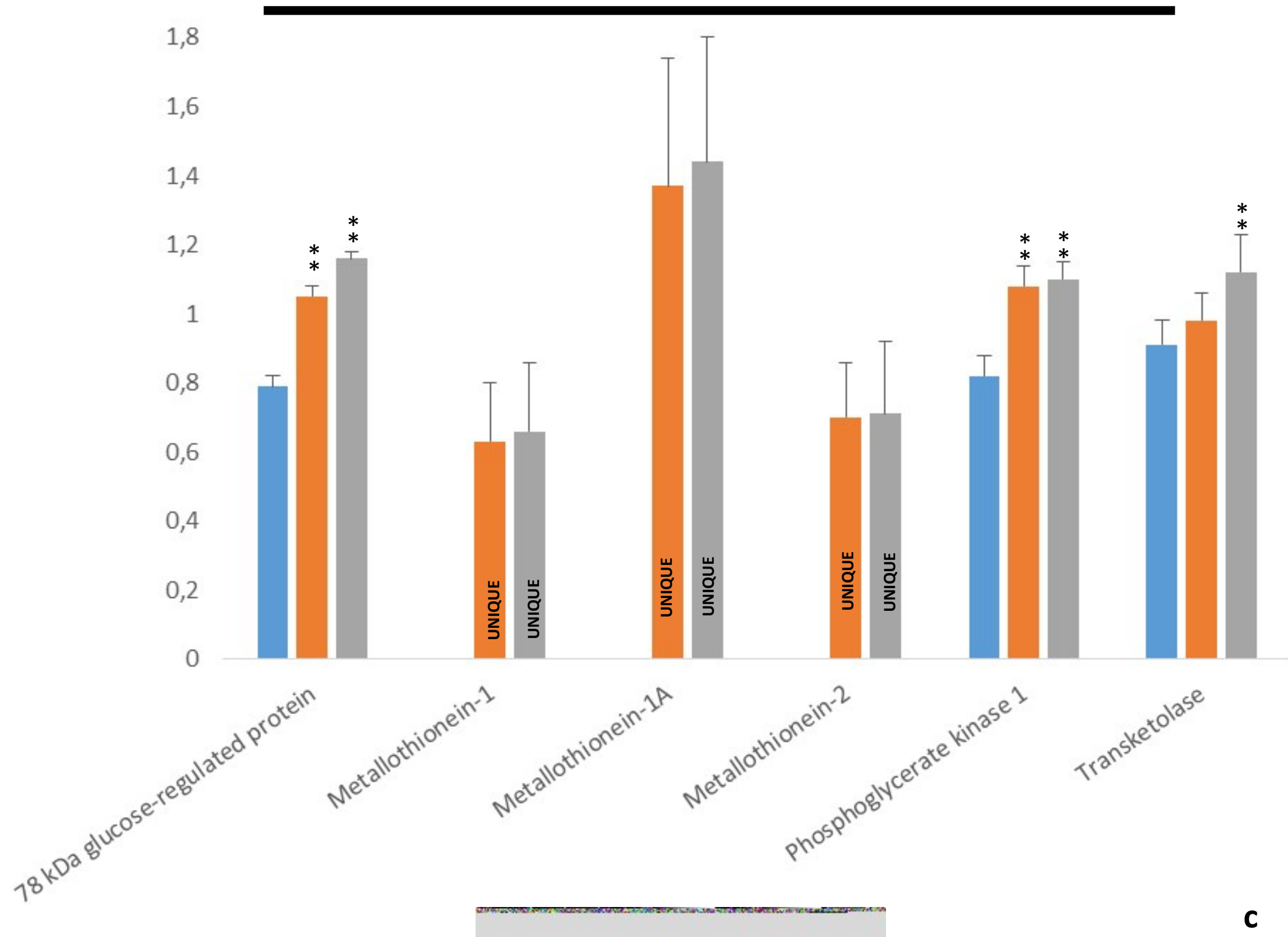




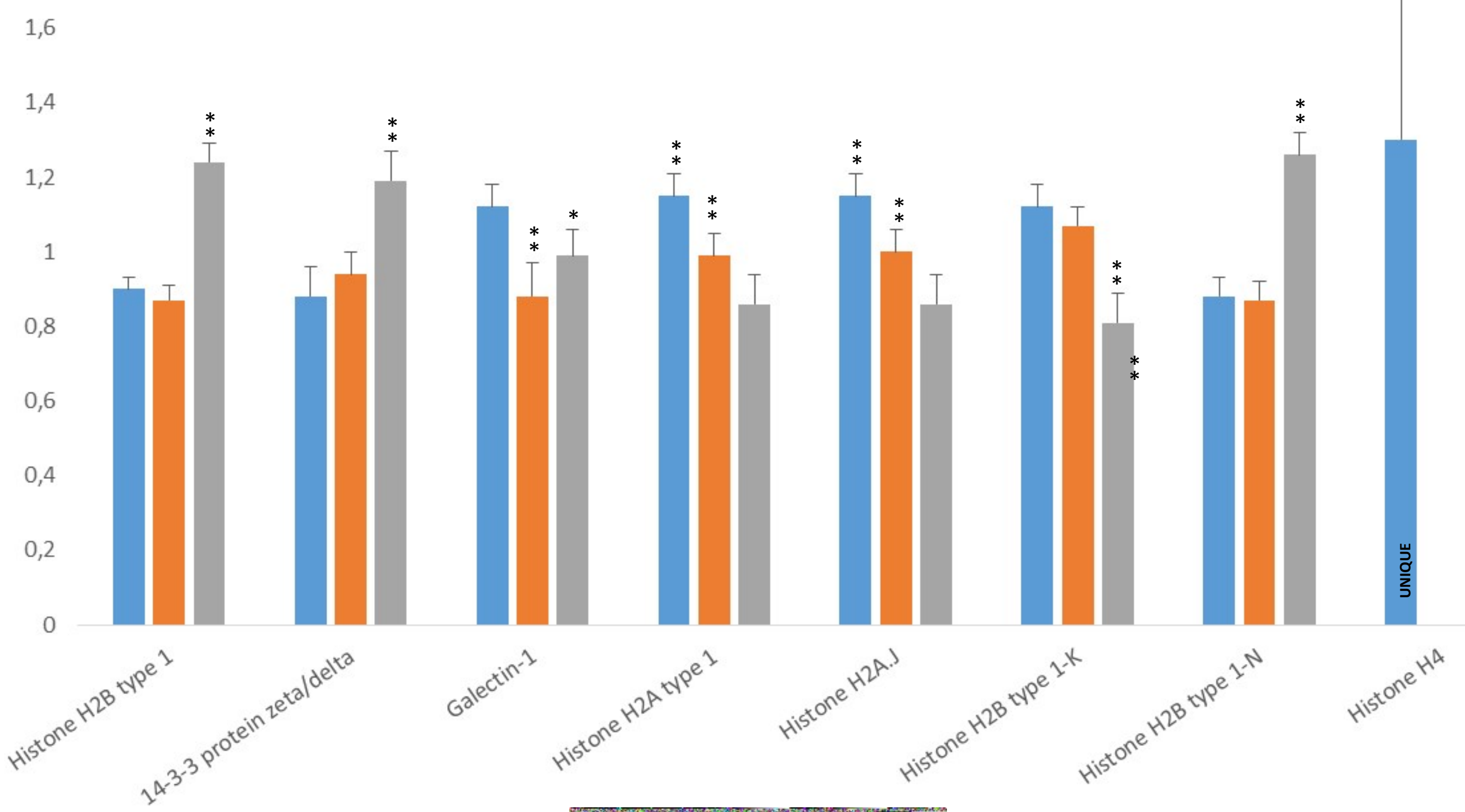




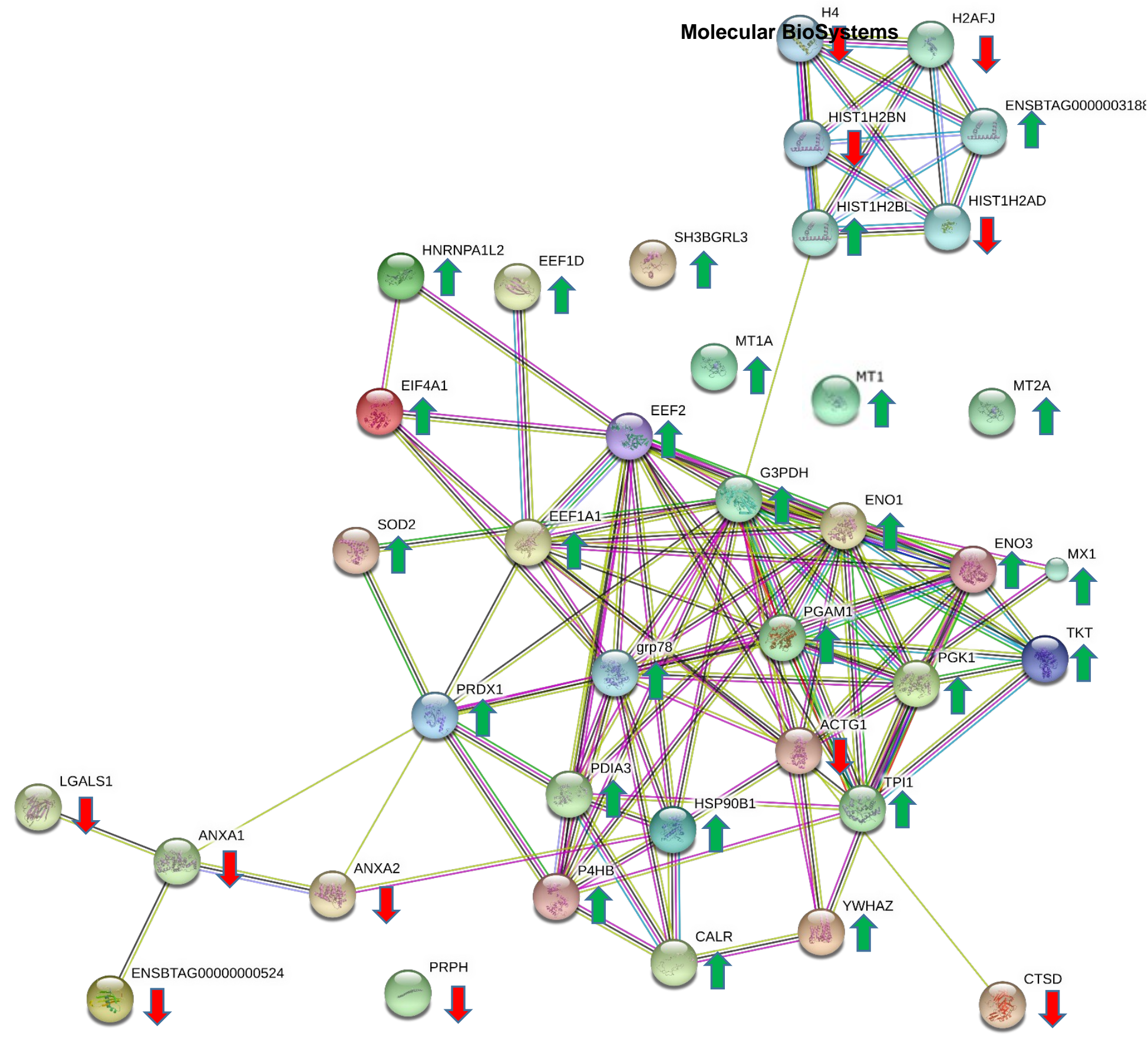

Page 28 of 31 


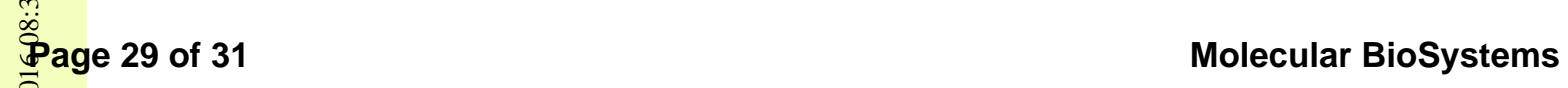

\begin{tabular}{|c|c|c|c|c|c|c|c|c|}
\hline \multirow{2}{*}{ Metabolism } & \multirow{2}{*}{ GO terms } & \multirow{2}{*}{ Accession } & \multirow{2}{*}{ String name } & \multirow{2}{*}{ Description } & \multicolumn{2}{|c|}{ Ratio (Shotgun MS) } & \multicolumn{2}{|c|}{ Ratio (2DE) } \\
\hline & & & & & LPS8/CTRL & LPS16/CTRL & LPS8 vs CTRL & LPS16 vs CTRL \\
\hline \multirow{4}{*}{$\begin{array}{l}\text { Structural/ } \\
\text { Cytoskeleton }\end{array}$} & structural constituent of cytoskeleton & P63258 & ACTG1 & Actin, cytoplasmic 2 & $\downarrow 0.771051593 *$ & $\downarrow 0.718923724^{*}$ & & \\
\hline & $\begin{array}{l}\text { intermediate filament cytoskeleton } \\
\text { organization, extracellular exosome }\end{array}$ & A6QQJ3 & PRPH & Peripherin & $\downarrow 0.683861412^{*}$ & 0.923116348 & & \\
\hline & $\begin{array}{l}\text { Proteolysis, hydrolase activity, } \\
\text { extracellular region }\end{array}$ & P80209 & CTSD & Cathepsin & $\downarrow 0.612626388 *$ & & & \\
\hline & endopeptidase inhibitor activity & P25417 & $\begin{array}{l}\text { ENSBTAG00 } \\
000000524\end{array}$ & Cystatin-B & 个2.339646908* & & & \\
\hline \multirow{3}{*}{$\begin{array}{c}\text { Calcium } \\
\text { metabolism }\end{array}$} & calcium ion binding & P04272 & ANXA2 & Annexin A2 & $\downarrow 0.886920439 *$ & $\downarrow 0.895834136^{*}$ & $\downarrow 0,71564409^{*}$ & \\
\hline & calcium ion transmembrane transport & P46193 & ANXA1 & Annexin A1 & $\downarrow 0.913931182^{*}$ & $\downarrow 0.93239382^{*}$ & & \\
\hline & calcium ion binding, protein folding & P52193 & CALR & Calreticulin OS & $\uparrow 1.462284582^{*}$ & 个1.599994191* & & \\
\hline \multirow{5}{*}{$\begin{array}{c}\text { Energy } \\
\text { Metabolism }\end{array}$} & Gluconeogenesis, glycolytic process & Q3SZ62 & PGAM1 & Phosphoglycerate mutase & 个1.803988368* & $\uparrow 2.033991215^{*}$ & & \\
\hline & glycolytic process & P10096 & G3PDH & $\begin{array}{l}\text { Glyceraldehyde-3-phosphate } \\
\text { dehydrogenase }\end{array}$ & 个1.336427477* & 个1.390968147* & & \\
\hline & glycolytic process & Q5E956 & TPI1 & Triosephosphate isomerase & 个1.40494759558807* & $\begin{array}{l}\uparrow 1.5068177797 \\
2405^{*}\end{array}$ & & \\
\hline & glycolytic process & Q3ZC09 & ENO3 & Beta-enolase OS & 个1.138828378* & 个1.349858824* & & \\
\hline & glycolytic process & Q9XSJ4 & ENO1 & Alpha-enolase & 个1.271249144* & 个1.377127754* & & \\
\hline \multirow{6}{*}{$\begin{array}{l}\text { Oxidative } \\
\text { stress } \\
\text { response }\end{array}$} & response to reactive oxygen species & Q5E947 & PRDX1 & Peroxiredoxin-1 & 0.970445534 & 个1.258600015* & & \\
\hline & cell redox homeostasis & P38657 & PDIA3 & $\begin{array}{l}\text { Protein disulfide-isomerase } \\
\qquad \mathrm{A} 3\end{array}$ & 个1.349858824* & 个1.50681778* & $\uparrow 1,34654270^{*}$ & \\
\hline & $\begin{array}{l}\text { response to hypoxia, protein folding, } \\
\text { response to stress }\end{array}$ & Q95M18 & HSP90B1 & Endoplasmin & 个1.296930074* & 个1.363425117* & & \\
\hline & cell redox homeostasis & Q3ZCL8 & SH3BGRL3 & $\begin{array}{l}\text { SH3 domain-binding glutamic } \\
\text { acid-rich-like protein } 3\end{array}$ & $\leftrightarrow$ & 个1.246076729* & & \\
\hline & $\begin{array}{l}\text { superoxide dismutase activity, } \\
\text { oxidative stress response }\end{array}$ & P41976 & SOD2 & Superoxide dismutase & & & $\uparrow 1,32768258^{*}$ & $\uparrow 1,491990^{* *}$ \\
\hline & protein folding & P05307 & $\mathrm{P} 4 \mathrm{HB}$ & Protein disulfide-isomerase & 个1.3771277544* & 个1.462284582* & & \\
\hline \multirow{2}{*}{$\begin{array}{c}\text { Trans/ation } \\
\text { Process/prote } \\
\text { in synthesis }\end{array}$} & Protein biosynthesis & P68103 & EEF1A1 & Elongation factor 1-alpha & 个1.138828378* & 个1.173510867* & & \\
\hline & $\begin{array}{l}\text { Translation, translational elongation, } \\
\text { signal transduction }\end{array}$ & A5D989 & EEF1D & Elongation factor 1-delta & 个1.15027379954284* & 个1.50681778* & & \\
\hline
\end{tabular}




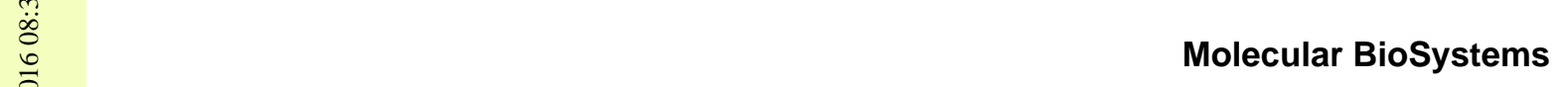

\begin{tabular}{|c|c|c|c|c|c|c|c|c|}
\hline & $\begin{array}{l}\text { translational initiation, regulation of } \\
\text { gene expression, }\end{array}$ & Q3SZ54 & EIF4A1 & $\begin{array}{l}\text { Eukaryotic initiation factor } \\
\qquad 4 \mathrm{~A}-\mathrm{I}\end{array}$ & 个* & $\leftrightarrow$ & $\uparrow 1,57531^{* * *}$ & \\
\hline & mRNA processing & P09867 & HNRNPA1L2 & $\begin{array}{l}\text { Heterogeneous nuclear } \\
\text { ribonucleoprotein A1 }\end{array}$ & $\leftrightarrow$ & 个1.271249144* & & \\
\hline \multirow{6}{*}{$\begin{array}{l}\text { Regulation of } \\
\text { cell cycle and } \\
\text { proliferation }\end{array}$} & regulation of growth & Q6B855 & TKT & Transketolase & 个1.072508182 & $1.233678052 \uparrow$ & 个1,36185114* & $\uparrow 1,36639^{*}$ \\
\hline & epithelial cell differentiation & Q3TOP6 & PGK1 & Phosphoglycerate kinase 1 & 个1.309964465* & 个1.349858824* & $\uparrow 2,2031346^{*}$ & \\
\hline & positive regulation of cell migration & QOVCX2 & grp78 & $\begin{array}{l}78 \mathrm{kDa} \text { glucose-regulated } \\
\text { protein }\end{array}$ & 个1.336427477* & 个1.476980773* & & \\
\hline & $\begin{array}{l}\text { negative regulation of growth, cellular } \\
\text { response to zinc ion }\end{array}$ & P58280 & MT1 & Metallothionein-1 & 个Unique LPS8* & & & \\
\hline & $\begin{array}{l}\text { negative regulation of growth, cellular } \\
\text { response to zinc ion }\end{array}$ & P67983 & MT1A & Metallothionein-1A & 个Unique LPS8* & & & \\
\hline & $\begin{array}{l}\text { negative regulation of growth, cellular } \\
\text { response to zinc ion }\end{array}$ & P68301 & MT2A & Metallothionein-2 & 个Unique LPS8* & & & \\
\hline \multirow{4}{*}{$\begin{array}{l}\text { Immune } \\
\text { response }\end{array}$} & $\begin{array}{l}\text { innate immune response in mucosa, } \\
\text { antibacterial humoral response, } \\
\text { defense response to Gram-positive } \\
\text { bacterium }\end{array}$ & P62808 & $\begin{array}{l}\text { ENSBTAG00 } \\
000031889\end{array}$ & Histone H2B type 1 & 0.970445534 & 个1.377127754* & & \\
\hline & protein domain specific binding & P63103 & YWHAZ & 14-3-3 protein zeta/delta & $\leftrightarrow$ & 个1.349858824* & & \\
\hline & $\begin{array}{l}\text { differentiation, positive regulation of } \\
\text { I-kappaB kinase/NF-kappaB signaling, } \\
\text { T cell costimulation }\end{array}$ & P11116 & LGALS1 & Galectin-1 & $\begin{array}{c}\downarrow 0.786627865286354 \\
*\end{array}$ & $\downarrow 0.886920439^{*}$ & & \\
\hline & innate immune response & P79135 & MX1_BOVIN & $\begin{array}{l}\text { Interferon-induced GTP- } \\
\text { binding protein Mx1 }\end{array}$ & & & $\uparrow 2,519244^{* *}$ & 个2,843155** \\
\hline \multirow{5}{*}{$\begin{array}{l}\text { Chromatin } \\
\text { and DNA } \\
\text { binding }\end{array}$} & $\begin{array}{l}\text { DNA binding, protein } \\
\text { heterodimerization activity }\end{array}$ & Q2M2T1 & HIST1H2BN & Histone H2B type 1-K & 0.96078944 & $\downarrow 0.726149042^{*}$ & & \\
\hline & $\begin{array}{l}\text { chromatin organization, chromatin } \\
\text { silencing }\end{array}$ & Pocos9 & $\begin{array}{l}\text { ENSBTAG00 } \\
000039492\end{array}$ & Histone H2A type 1 & $\begin{array}{c}\downarrow 0.852143792013715 \\
*\end{array}$ & $\downarrow 0.740818212^{*}$ & & \\
\hline & $\begin{array}{l}\text { chromatin organization, chromatin } \\
\text { silencing }\end{array}$ & Q3ZBX9 & H2AFJ & Histone H2A.J & $\downarrow 0.869358235^{*}$ & $\downarrow 0.740818212^{*}$ & & \\
\hline & $\begin{array}{l}\text { DNA binding, protein } \\
\text { heterodimerization activity }\end{array}$ & Q32L48 & HIST1H2BL & Histone H2B type 1-N & 0.990049834 & 个1.433329435* & & \\
\hline & $\begin{array}{l}\text { histone binding, extracellular } \\
\text { exosome, DNA replication-dependent } \\
\text { nucleosome assembly }\end{array}$ & P62803 & $\begin{array}{l}\text { ENSBTAG00 } \\
000040277\end{array}$ & Histone $\mathrm{H} 4$ & $\downarrow$ Unique CTRL* & & & \\
\hline
\end{tabular}




\section{Page 31 of 31}

Table 1. Table representing the whole dataset of the differentially expressed proteins identified through shtogun MS analysis and $2 \mathrm{D}$ electrophoresis $\left({ }^{*} \mathrm{p}<0.05\right.$, $\left.{ }^{* *} \mathrm{p}<0.01, * * * \mathrm{p}<0.001\right)$. 